\title{
بحوث ودراسات
}

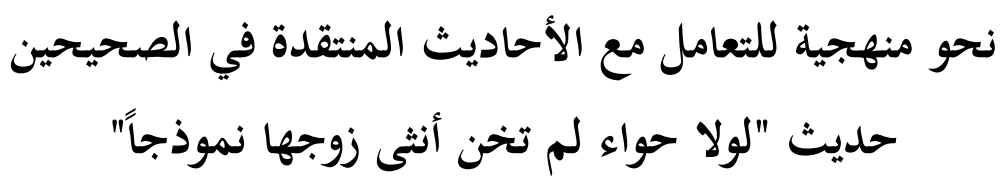

نماء محمد البنا

$$
\begin{aligned}
& \text { الملخص }
\end{aligned}
$$

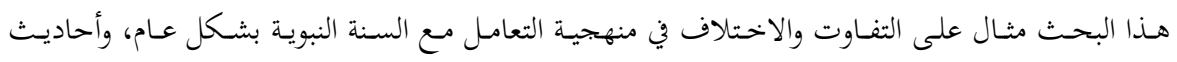

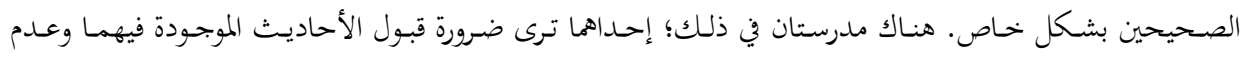

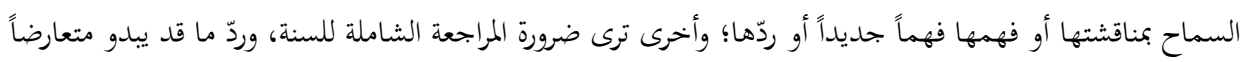

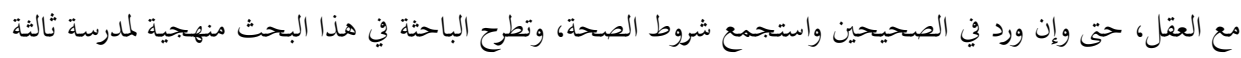

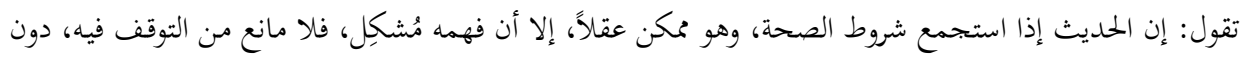

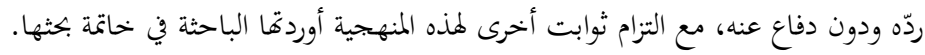

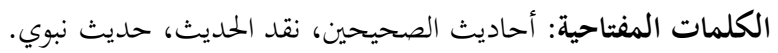

\section{"Towards a Methodology of Dealing with Critiqued Hadiths in the Two Sahihs"}

\begin{abstract}
This study is an example of the differences existing among scholars in the methodology of dealing with the sunnah of prophet Muhammad peace be upon him, and

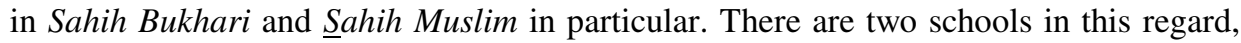
the first adopts the idea of accepting hadiths of the two sahihs, understanding them as they are, and not dismissing them. The second school allows a comprehensive revision of the sunnah, and rejects what seems in conflict with reason, even if the hadith appears in one of the two sahihs. The author presents a third school which says: if the hadith has all the conditions of being sahih and is in line with reason, but it presents a problem in its understanding, there will be no problem to question the hadith without rejecting it all together.
\end{abstract}

Keywords: prophetic hadith, critiquing hadith, sahihan.

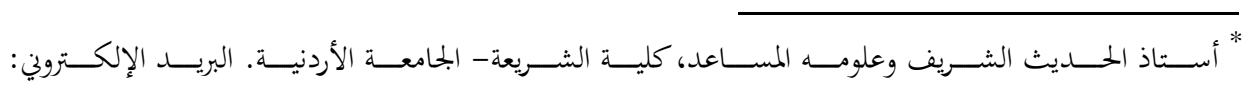

$$
\begin{aligned}
& \text { nmbanna@gmail.com }
\end{aligned}
$$

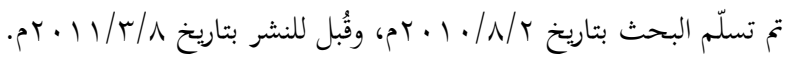




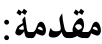

اختلفت منهجية المشتغلين والمهتمين بالحديث النبوي في التعامل مع السنة النبوية،

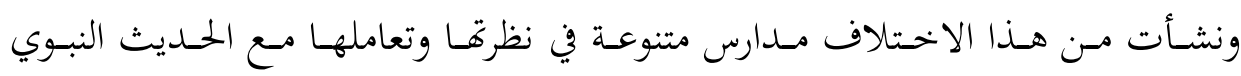

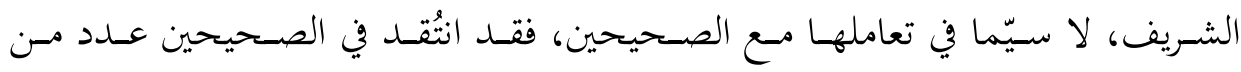

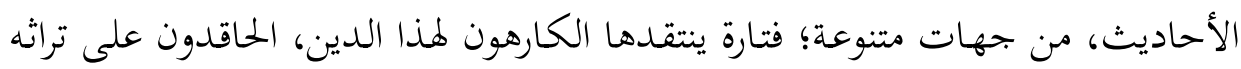

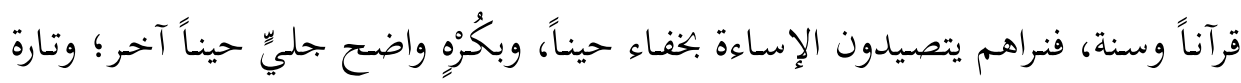

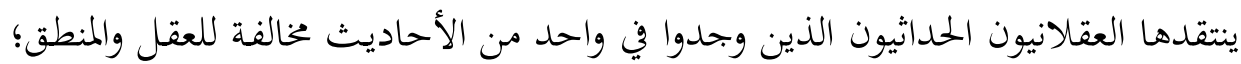

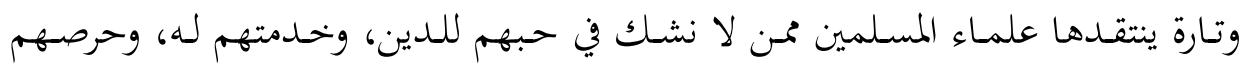

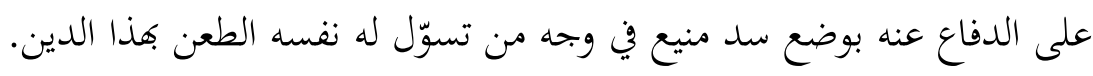

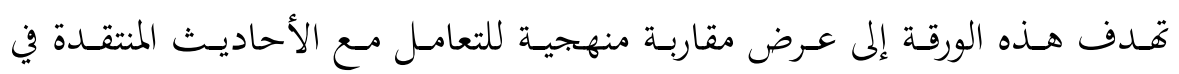

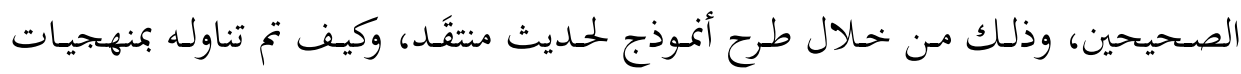

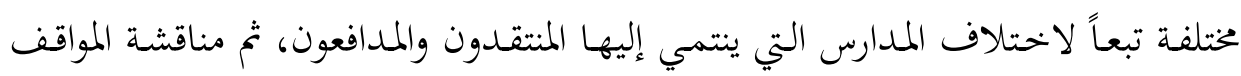
والترجيح بينها.

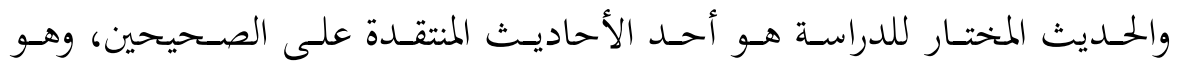

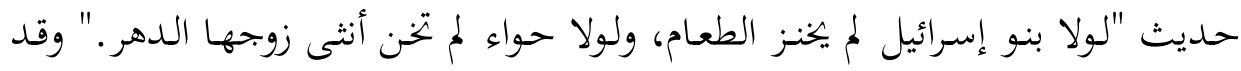

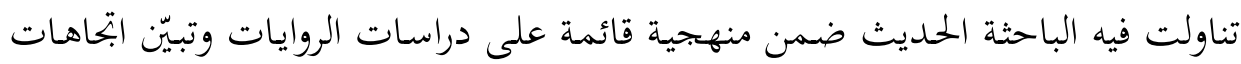
الباحثين في التعامل مع الحديث ومناقشتها.

\section{أولاً: منهجية التعامل مع السنة النبوية}

طبيعة البشر في كل زمـان ومكان أن يختلف تعاملهم مع الأشياء والأفكار، تبعاً

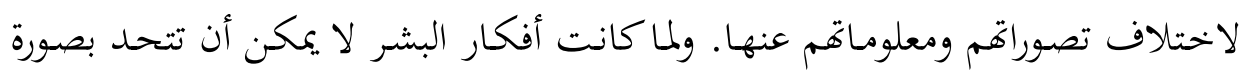

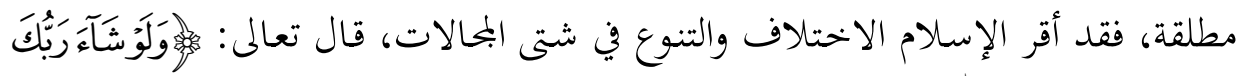

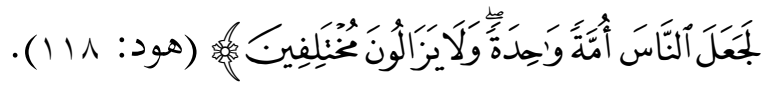


ولأن أفكار الإنسان وتصوّراته تنبع من معرفته بالمبادئ والثقافات وفهمهه للبيئة التي

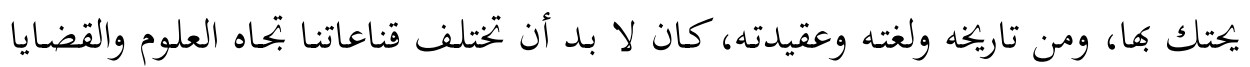

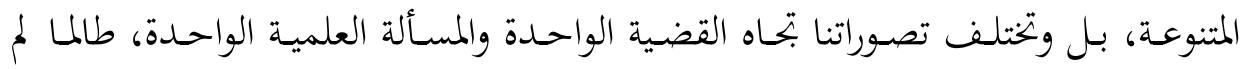

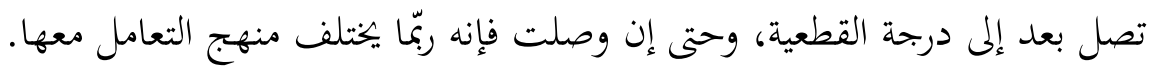
ومسن أهـم العلوم التي نلمس فيهـا اختلافاً في منهجيـة التعامل معهـا -مـع التسليم

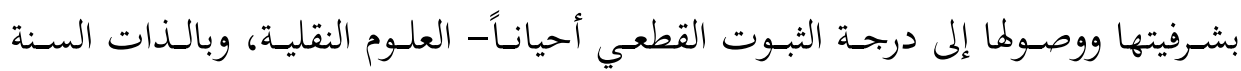
النبوية؛ لأن القرآن الكريم ثابت ثبوتاً قطعياً في كل حرف من من حروفه، فلا يملك أحدهم أن يناقش في ثبوته، إلا أن هناك مساحة جيدة للنقاش في مدلول آياته وفهمها وتنزيلها

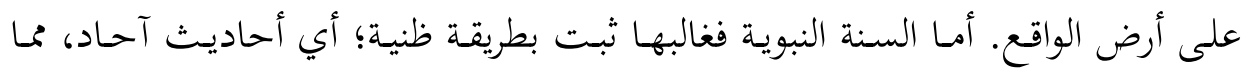

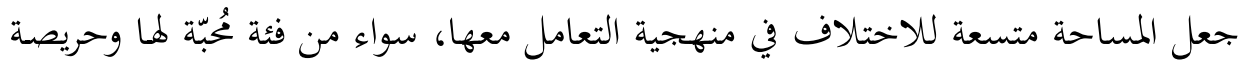

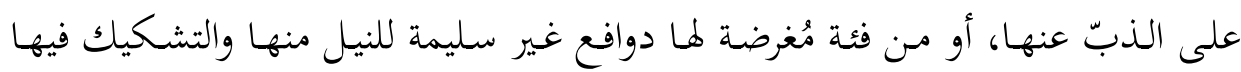
ثبوتاً ومدلولاً.

وبشكل عـام يمكننا القول إنّ اختلاف منهجية التعامل مع العلوم النقلية يمكـن أن

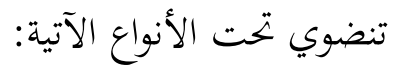
- النـوع الأول: التسـليم التـام بثبوكها، وهـــا بحمـع عليـه بالنسـبة للقـرآن الكـيم. والاختلاف هنا يظهر في فهم هذه النصوص، وكيفية التعامل معها، وكيفية تنزيلها على

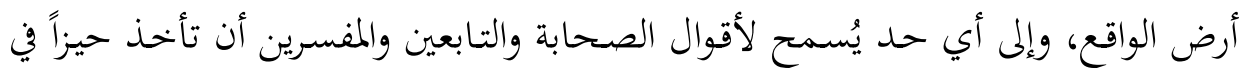
فهمها وتنزيلها واقعياً.

- النـوع الثـاني: التسـليم التـام لـبعض نصـوص السـنة النبويـة؛ وأقصــ هنـاكتـابي صحيح البخاري وصحيح مسلم، وعدم التسليم لغيرهما من النصوص، إلا إذا نصّ أحد

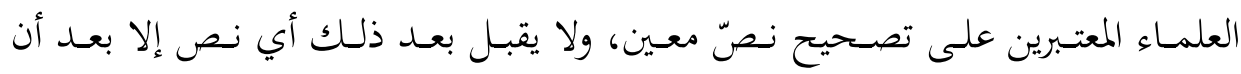

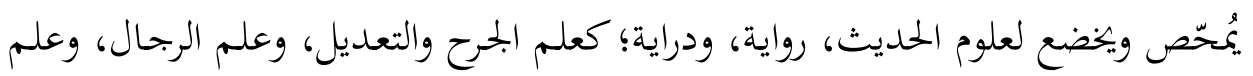
العلل، وعلوم الحديث الأخرى المعنية بالتصحيح والتضعيف والقبول والرد. 
ويظهـر الاخستلاف هنـا في منهجيـة التصـحيح والتضعيف، وفي قبـول أحكـام مـن

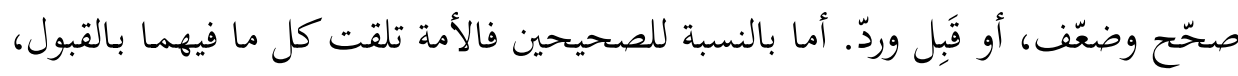
ونصّ علماء الحديث على أن كل ما فيهما ثابت ومقبول وصحيح حديثياً.

- النوع الثالثث: عـدم التسليم لكل نصـوص السـنة النبويـة بمـا فيهـا الصحيحين؛

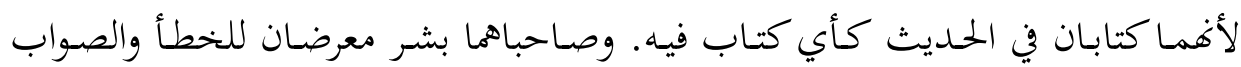

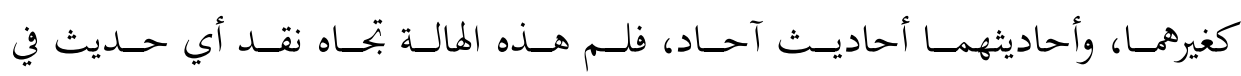
الصحيحين؟

والاختلاف هنا يكمن في طبيعة التعامل مع الصحيحين، وأخلاقيات القبول والرد

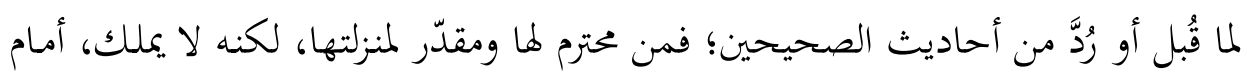

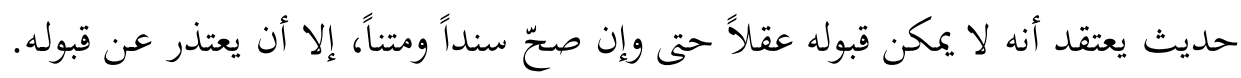
وهؤلاء لا يُشك في نواياهم وحبهم للحدمة السّنة النبوية.

ومن متّهم لصاحبي الصحيحين بجنايتهم على هذا الدين، بما أودعوه من أحاديث

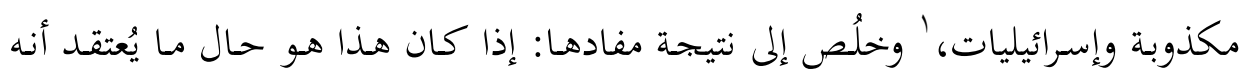

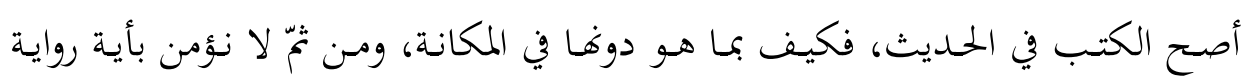

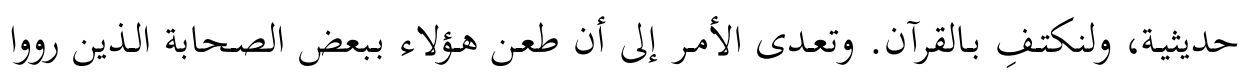
هذه الأحاديث.

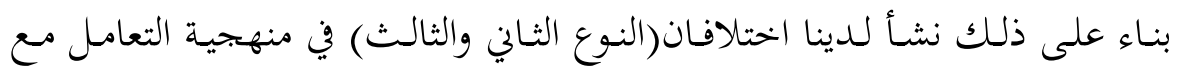

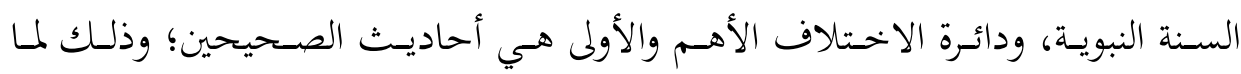

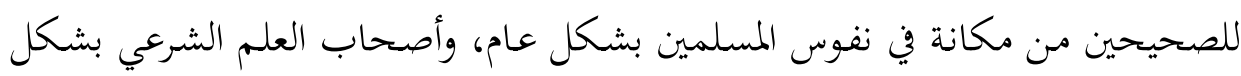
خاص، ولأن الصحيحين اكتسبا ثقة وصحة علمية زمانية، جعلت التعرض لأحاديثهما مرفوضاً، وقد يتعدى الأمر إلى اتحام نوايا من يتعرض لهذه العذه الأحاديث. انعكست منهجية هـاتين المدرستين في تعامل كل منهما مع الصحيحين، وبالذات

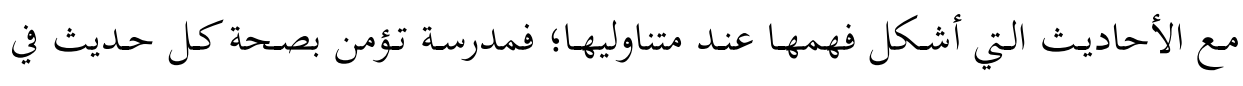
' انظر : أوزون، زكريا. جناية البخاري إنقاذ الدين من إمام المحدثين، بيروت: رياض الريس، طا، ع . . به. 
الصحيحين، وتتبنى الدفاع عن كل ما فيهما من أحاديث. وإن أُشكل فَهْم بعض المتون

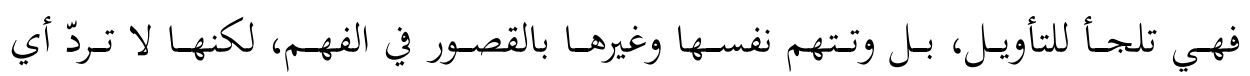

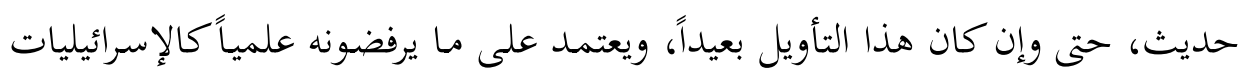

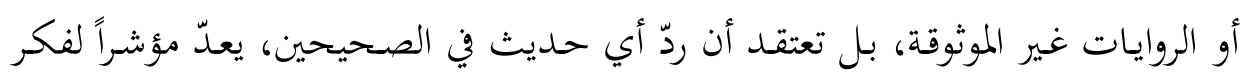
غير سوي، ينبغي الاحتراز ممن يذهب إليه.

ومدرسة أخرى ثُخضع كل حديث في الصحيحين لنقد عقلي، فصحة السند والمتنن

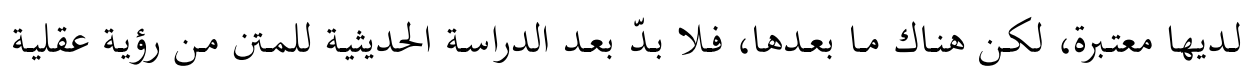

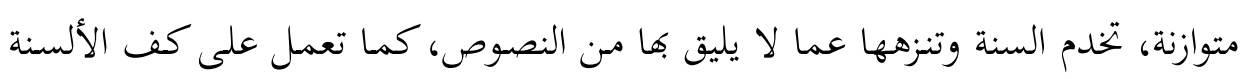

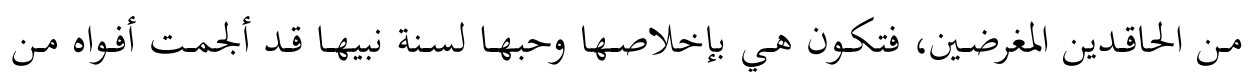

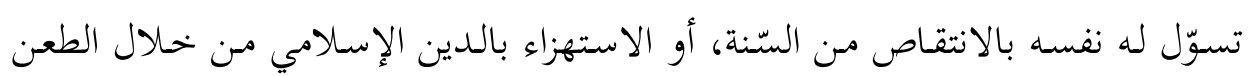

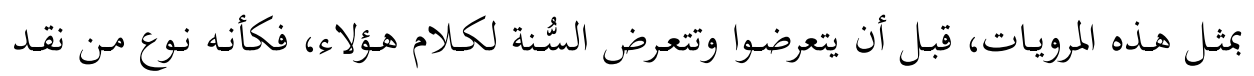

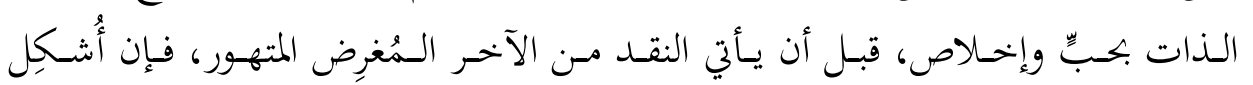
عندهم حديث موجود في الصحيحين، واستجمع كل شرائط الصحة، وله علاقة بأهل

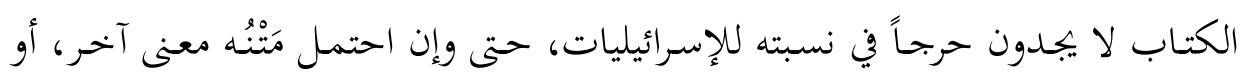

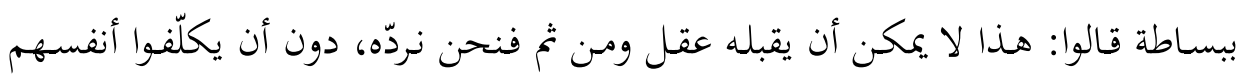

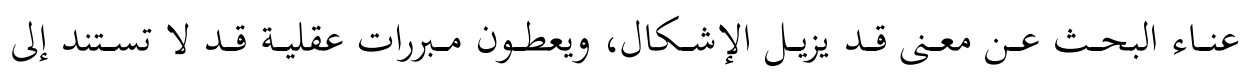
منهجية علمية. يلاحظ أن كالاً مـن المدرستين لا ينقصه حسن النوايا، ولكنهما جانبـا الصواب في

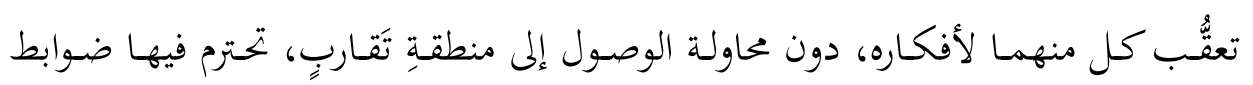

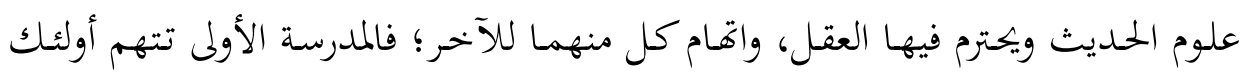

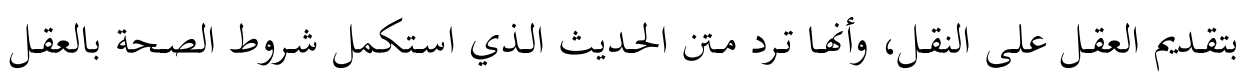

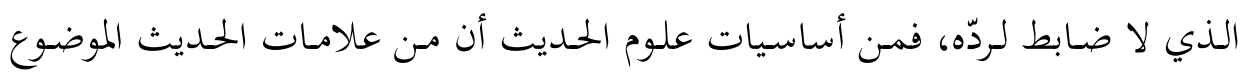
مخالفته لصريح العقل، لكن هؤلاء يردون الحديث بشبهة عدم قناعتهم بمضمونه عقلاً. 
والمدرسة الثانية تتهم الأولى بالجمود والوقوف خلف قواعد حديثية جامدة، وعـدم

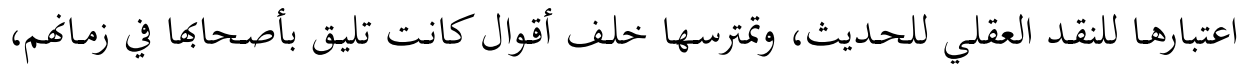
لكنها لا تليق بزمن العلم والتقدم والتطور، وعدم قبولهم مناقشة الحديث بمنطق بائد، وهو أنه موجود في الصحيحين وكفى.

مـن هنـا جـاءت هـذه الدراسـة للتقريـب بـين المدرستين، دون تحيز لإحـداهما على أخرى، إلا التحيز للحق، والعقل الدال على الحق، قدر الاستطاعة، ولماولة بناء منهجية

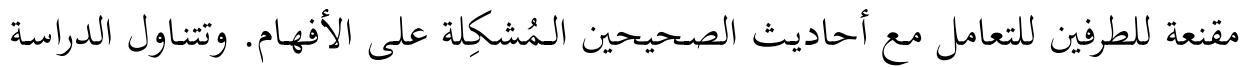
أحد هذه الأحاديث، بوصفه نموذجاً لمذه المنهجية، والله أسأل السداد والتوفيق.

\section{ثانياً: روايات الحديث وتخريجه}

انفرد الصحابي الجليل أبو هريرة برواية هذا الحمديث، ورواه عنه أربعة من الرواة، وهم:

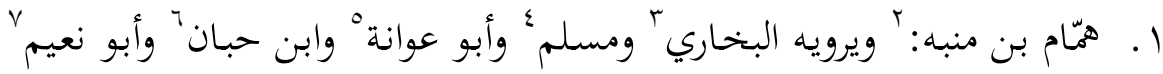

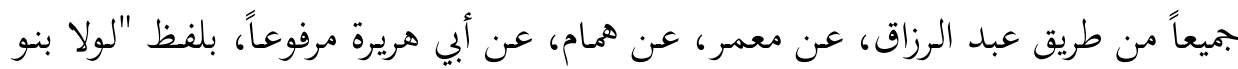

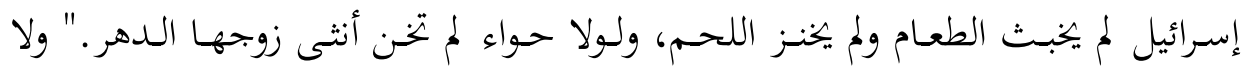
يوجد في رواية البخاري" لم يخبث الطعام."

' هو همام بن منبّه صاحب الصحيفة. ثقة، وحديثه في الصحيحين، قال عنه الذهبي: ثقة متقن، والصحيفة أكثرها في

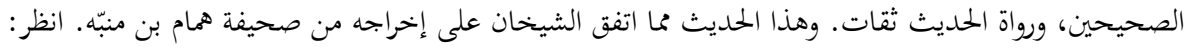

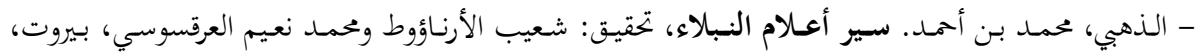

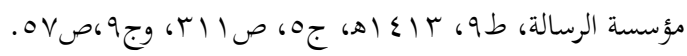

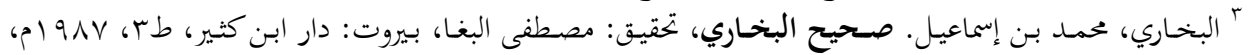

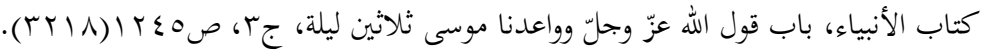

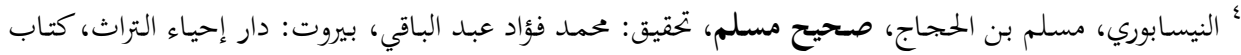

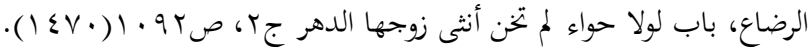

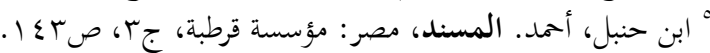

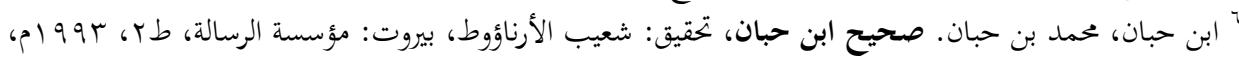

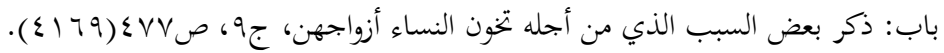

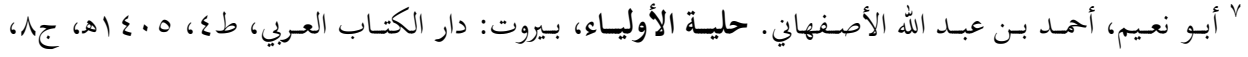


وعند البخاري^ رواية ثانية من طريق ابن المبارك، عن معمر، عن همام، عن أبي هريرة

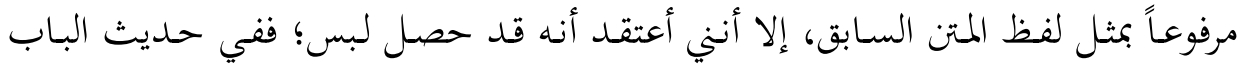

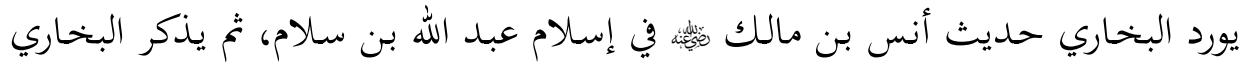

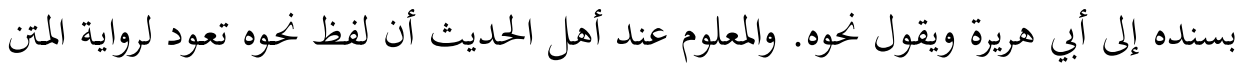
السابق من طريق آخر، ثم يأتي أحدهم -ولعلّه أحد النساخ- فيقول:

يعني لولا بنو إسرائيل لم يخنز اللحم، ولولا حواء لم تخن أنثى زوجها، فلا دليل أبداً

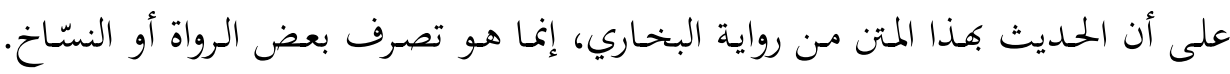

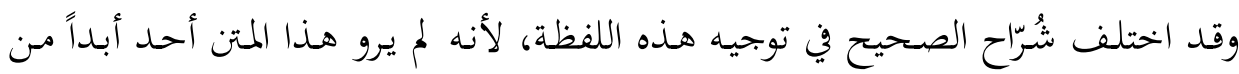

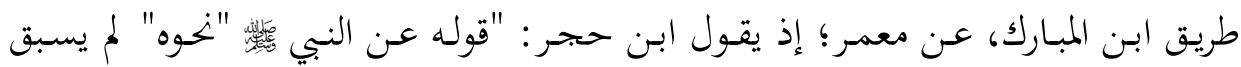

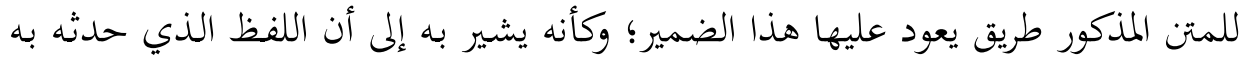
شيخه هو بمعنى اللفظ الذي ساقه، فكأنه كتب من حفظه وتردد في بعضه، ... يعني ولم

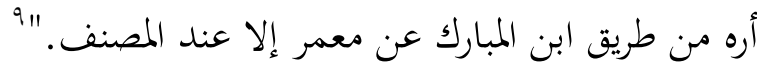

ويعترض العيني على كلام ابن حجر؛ إذ يقول: "هذا ما فيه كفاية للمقصود، ولا له التئام من جهة التركيب؛ لأن الذي يذوق دقائق التراكيب ما يرضى بهذا الذئي ذهرب ذكره، بل

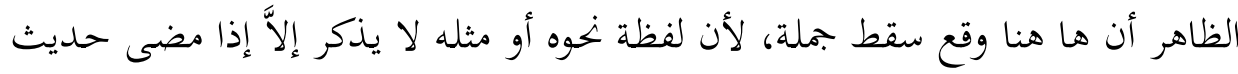

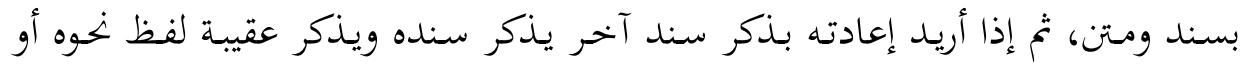

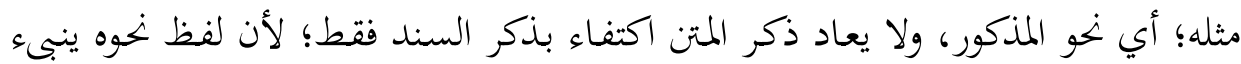

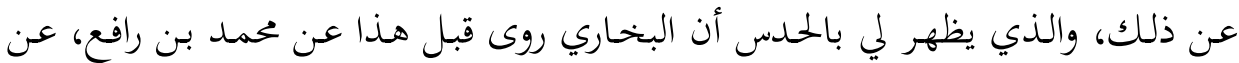

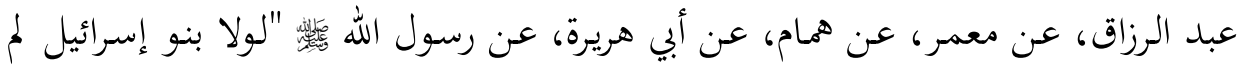

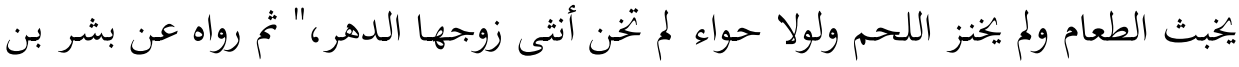

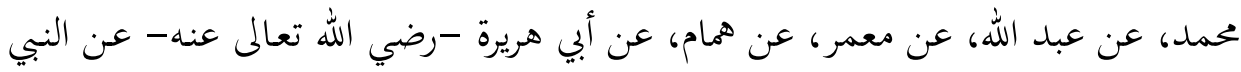
^ البخاري، صحيح البخاري، مرجع سابق، كتاب الأنبياء، باب قول الله تعالى وإذ قال ربك للملائكة إني جاعل في

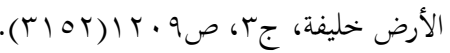
" ابن حجر العسقلاني. فتح الباري شرح صحيح البخاري، تحقيق: محب الدين الخطيب، بيروت: دار المعرفة، جج، 


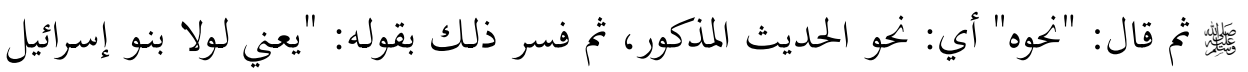

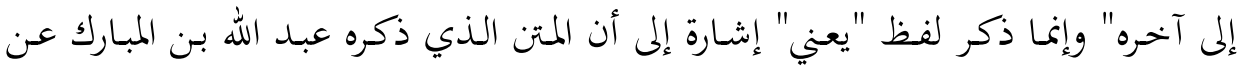

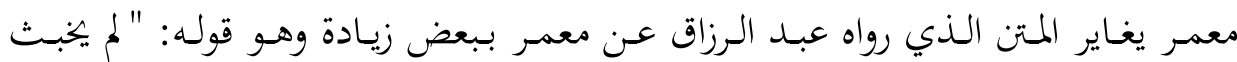

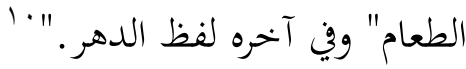

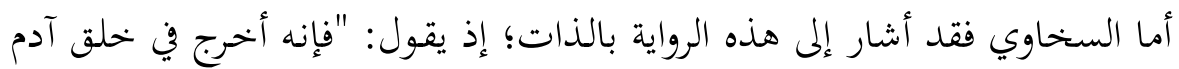

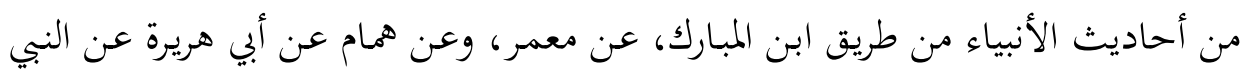

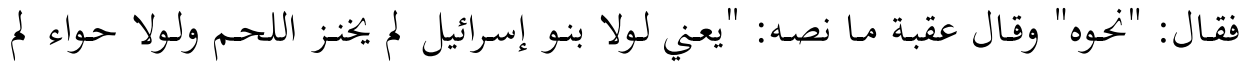

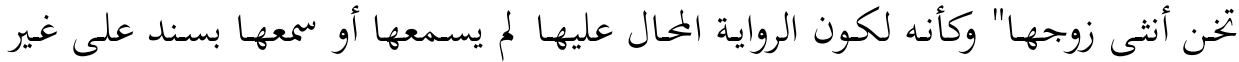

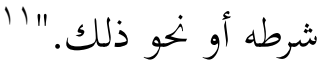
والذي أرجحه كما قلت سابقاً أن الرواية المحال عليها هي إسلام عبد الله بن سلام، ولعله إدخال من بعض النسّاخ في تفسير قوله نهوه، والله أعلم.

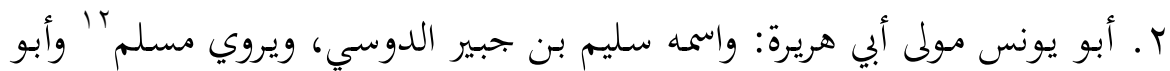

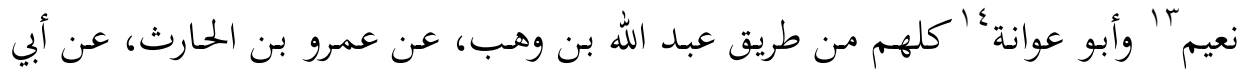

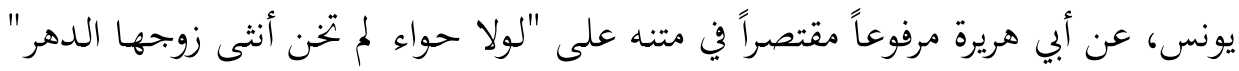
باستثناء كلمة الدهر عند أبي عوانة.

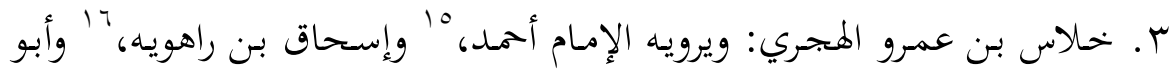

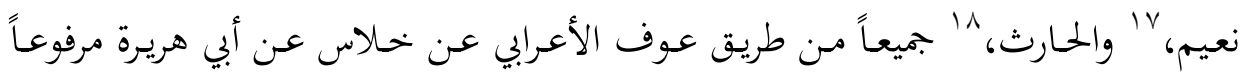
بمثل لفظ رواية همام.

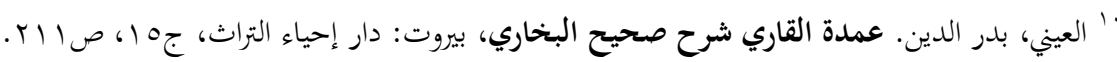

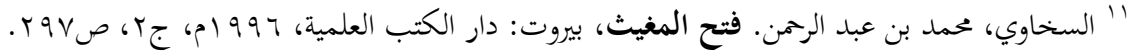

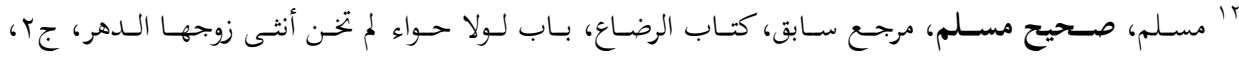
() (I)

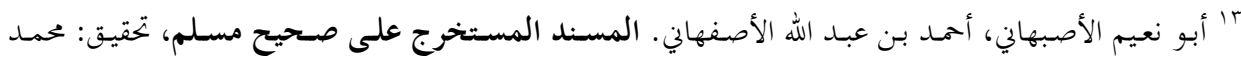

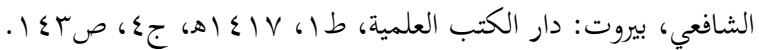

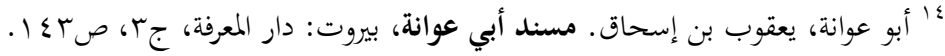

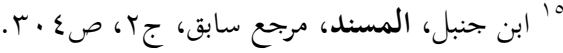




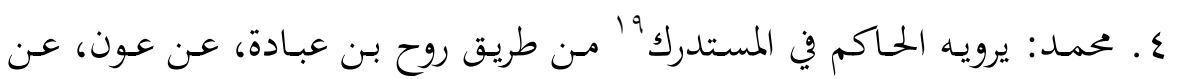

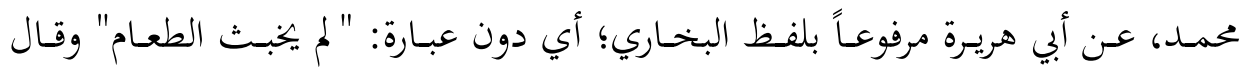
عقبة: "هذا حديث صحيح على شرط الشيخين ولم يخرجاه.

ثالثاً: اتجاهات الباحثين في التعامل مع الحديث

\section{1 ا ـ موقف من قَبِل الحديث:}

كل مَن تناول الحديث من الشراح المتقدمين قبِ الحديث -حسب ما وقفت عليهلجأوا للتأويل، لأن الحمديث، على ظاهره ولأول وهلة، يوقع في النفس توجساً مـن قبوله

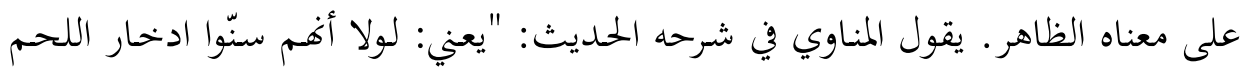

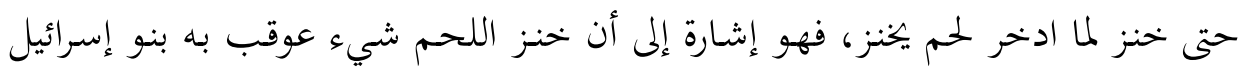

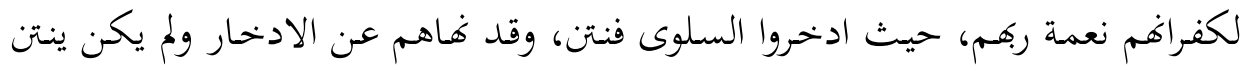

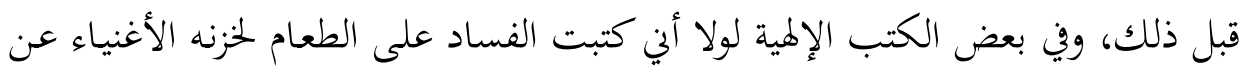
الفقراء، ولولا حواء.. يعني.. لولا خيانة حواء لآدم في إغوائه وتحريضه على مخالفة الأمر

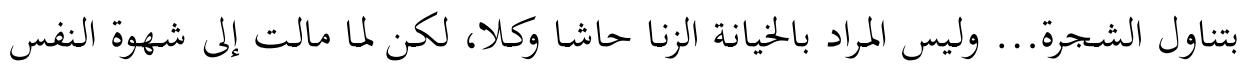

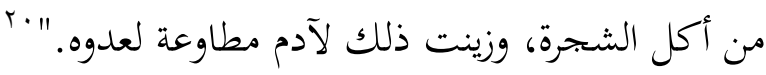

أمـا ابـن حجـر شـارح صـحيح البخـاري فيقـول: "قولهه لـولا بنـو إسـرائيل لم يخنـز

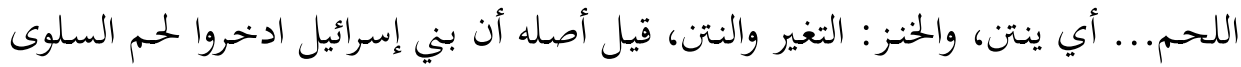

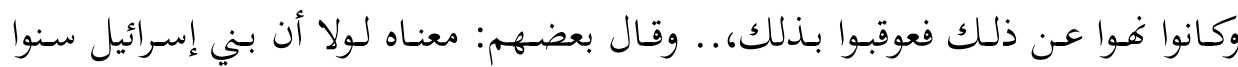

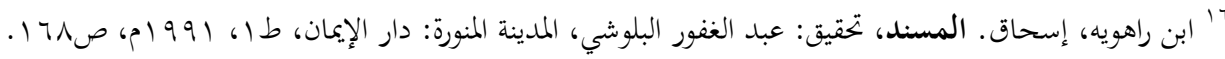

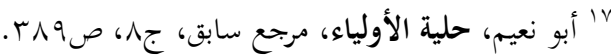

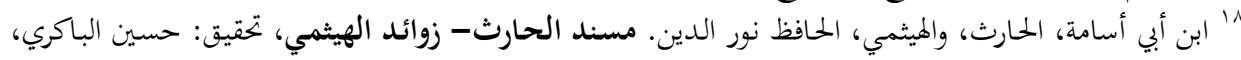

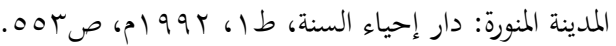

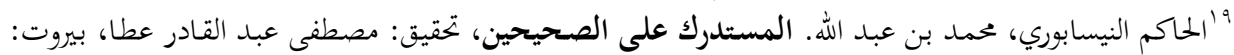

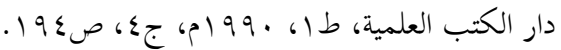

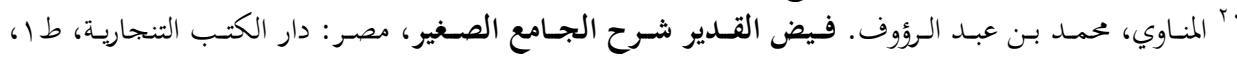


ادخار اللحم حتى أنتن لما ادخر فلم ينتن.... وقوله (لم تخن أنثى زوجها) فيه إشارة إلى ما

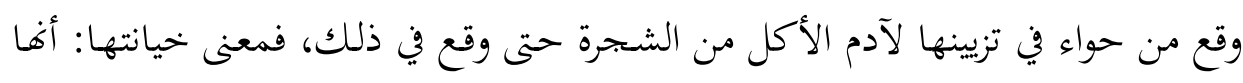

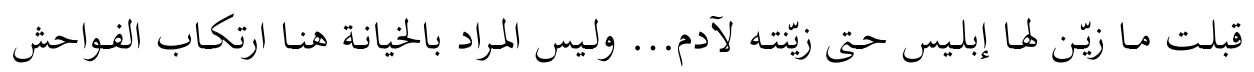

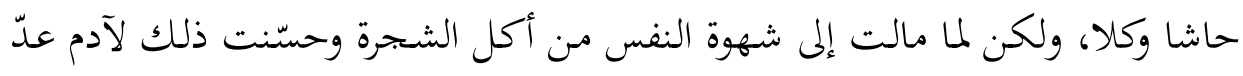

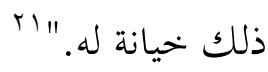

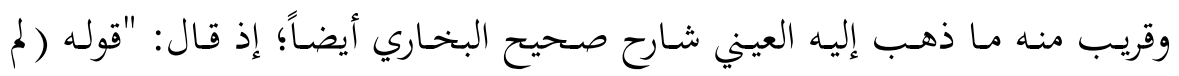

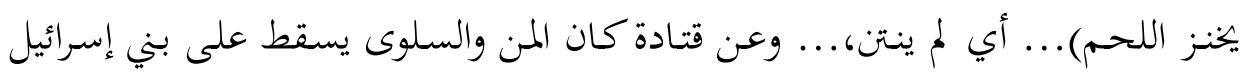
من طلوع الفجر إلى طلوع الشمس كسقوط الثلج، فيؤخذ منه بقدر ما يغني ذلك اليوم

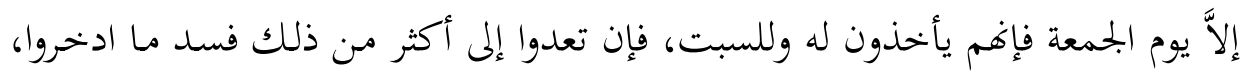

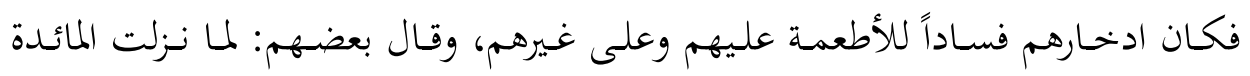

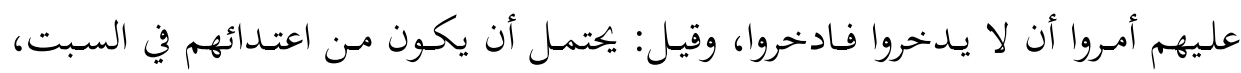

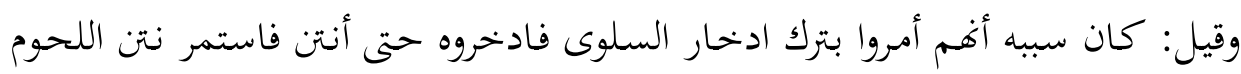

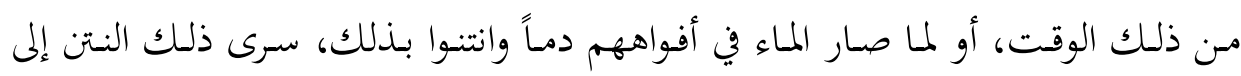

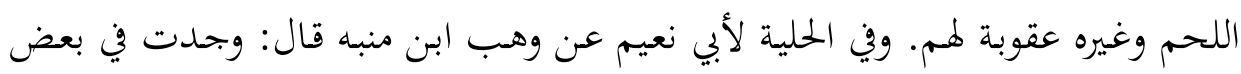

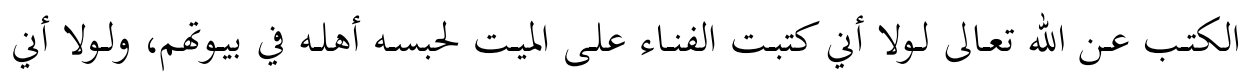

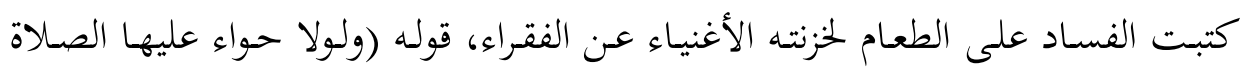

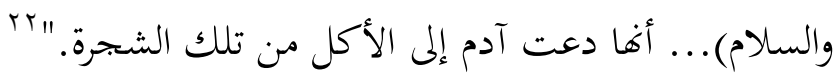

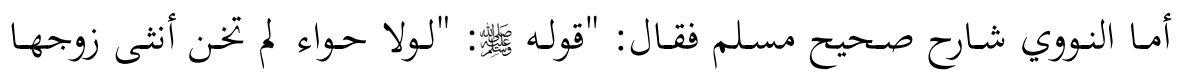

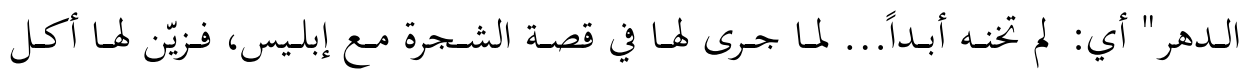

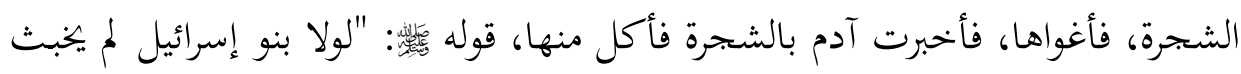

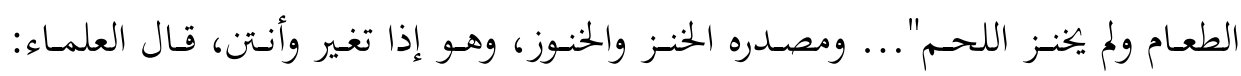

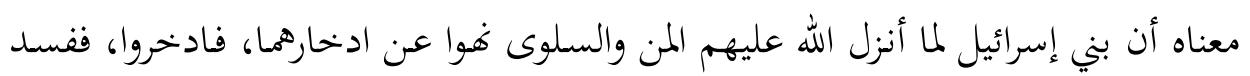

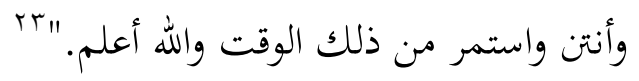

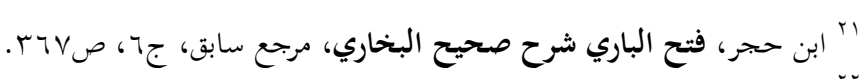

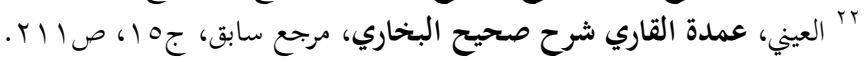

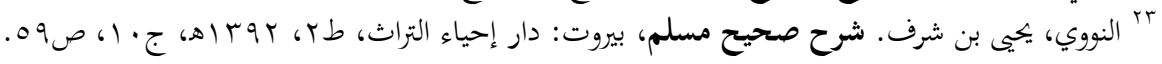




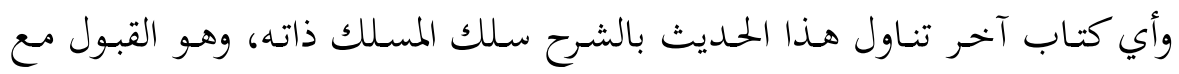

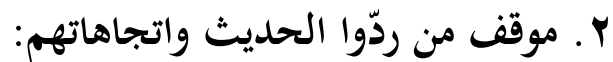

\section{أ. الاتجاه العقلي الحداثي العلماني:}

معظم من طعن في هذا الحديث انصبَّ طعنه على المتن، وتعددت عبارات هؤلاء

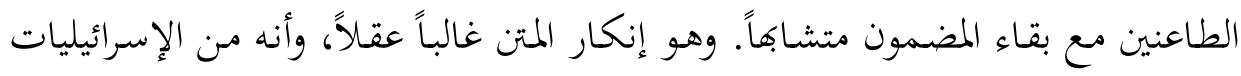

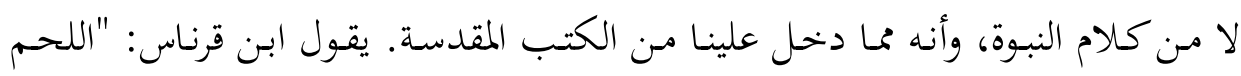

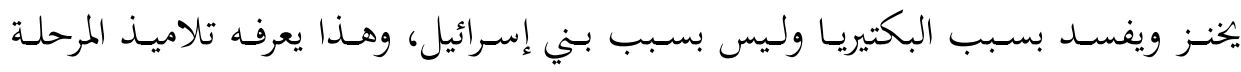

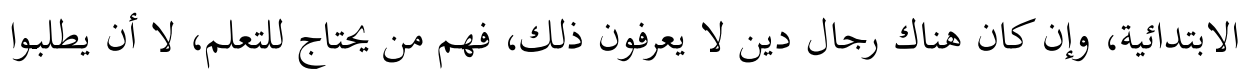

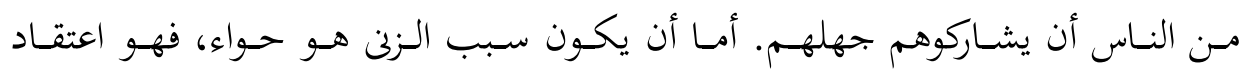

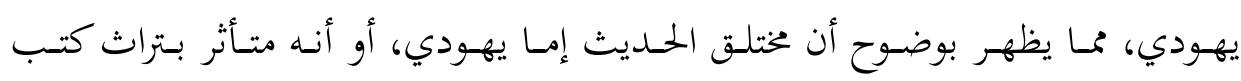

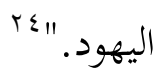

ومن أمثال ابن فرناس الحـداثي زكريا أوزون، الذي تناول هذا المتن في كتابه "جناية

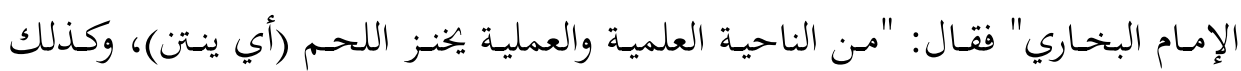

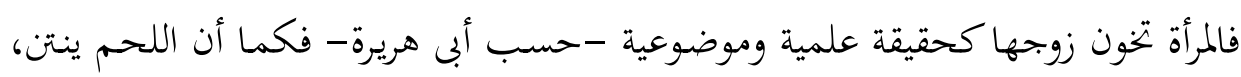

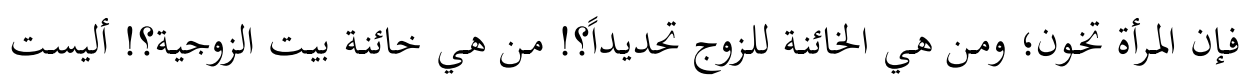

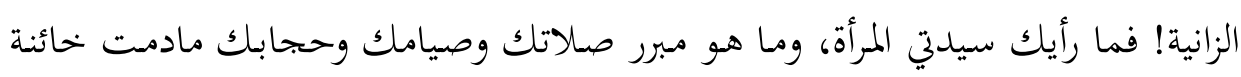

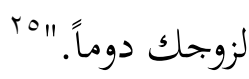

ومنهم أيضا سامر إسلامبولي؛ إذ يقول: "فهذا الحديث يثبت أن الخيانة في النساء

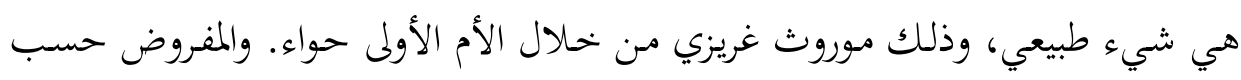

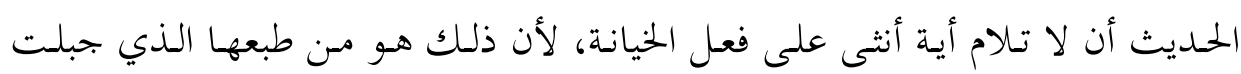


عليـا! والسؤال المطروح مـا هي خيانـة حواء؟ والجـواب التقليـدي هـو أفـا زيّنـت لآدم

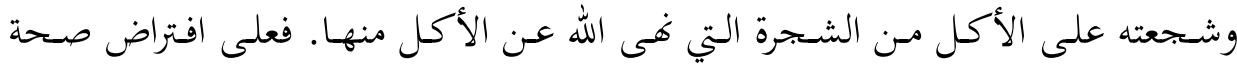

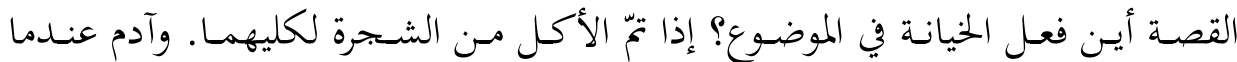
استجاب لها فذلك لهوى في نفسه، وقد انقاد للفعل بإرادته دون إجبار أو إكراه، فهو إنهو

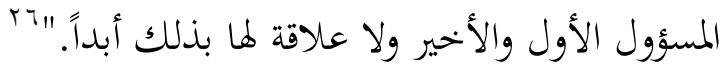
ومنهم صالح أبو بكر في كتابه الأضواء القرآنية؛ إذ يقول: "وبراهين الكذب على رسول الله في هذا الحديث تتبين في الآتي: أولاً: إن حسواء لم تكـن خائنسة لزوجها في يـوم مسن الأيـام، وإنما هي شـريكة لـه في

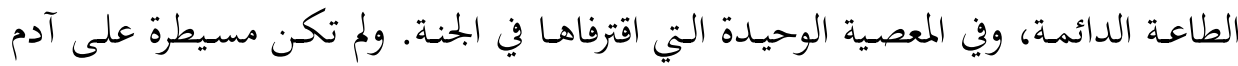

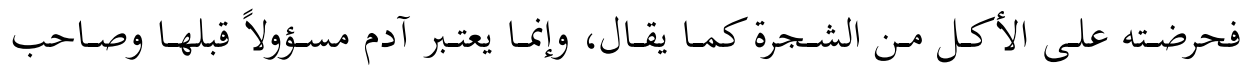

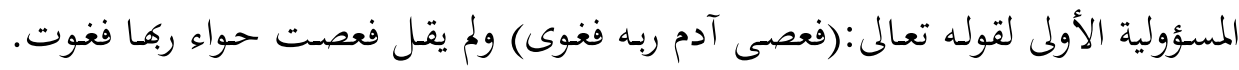

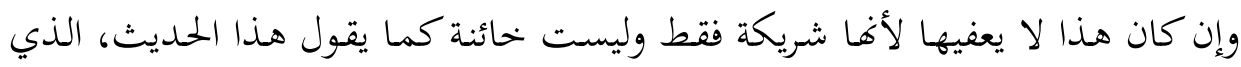

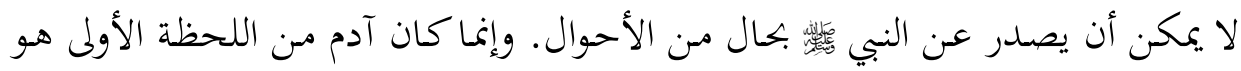
القوّام عليها كما هي سنة الله.

ثانيـاً: إن خيانـة الزوجـات لأزواجهن لم تكـن مسن نوعِ فعلتهـه حسواء مـع آدم طوال

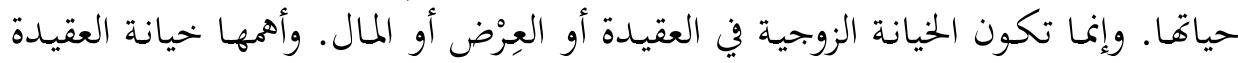

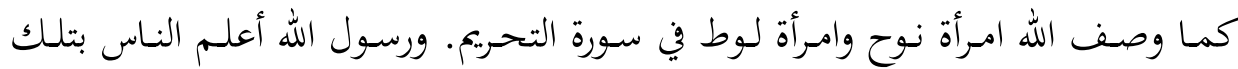
الحقيقة عن حواء أم المؤمنين والمؤمنات من الآدميين. ثالثاً: عجيب أن ينسب إلى النبي

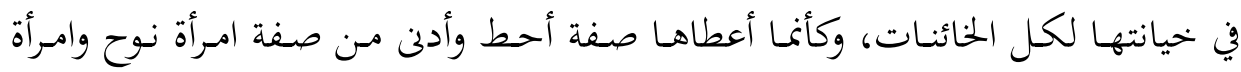

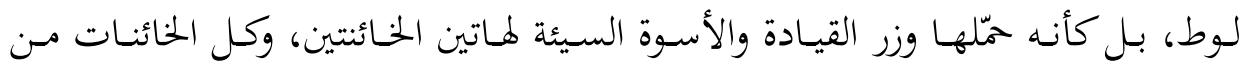

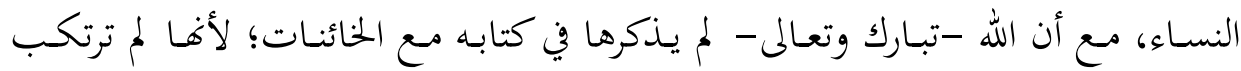

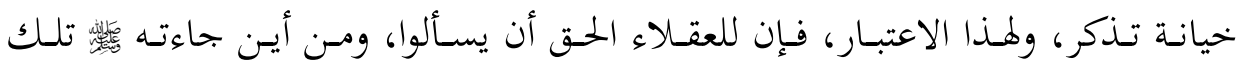

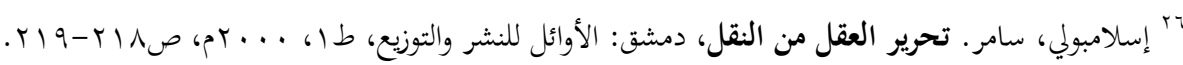


الحقيقة ما دامت لم تأته في القرآن الكريم؟ والحق أفا لم تأته ولم يقلها لأنه صاحب أعف

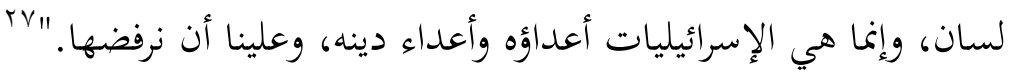

وعلى طريقهم يقول نيازي عز الدين: "وإذا سألنا من أين أتى مصدر العلم لممد

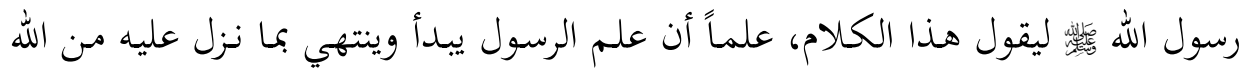

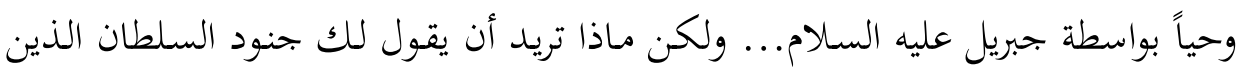

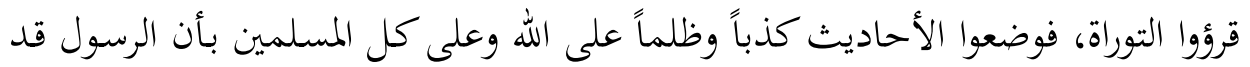

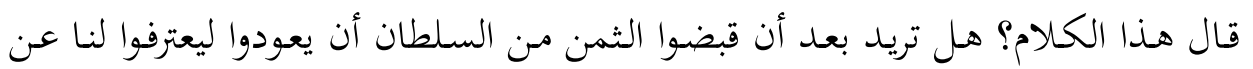

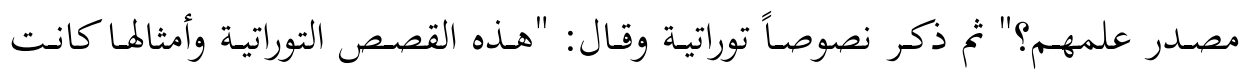
مصادر جنود السلطان للوحي الثاني الذي نسبوه ظلما لله ورسوله."

ومسن العلمـانيين مـن أفرد لهـذا الحـديث بالـذات دراسـة مفصـلة مثـل عبــ الحكـيم

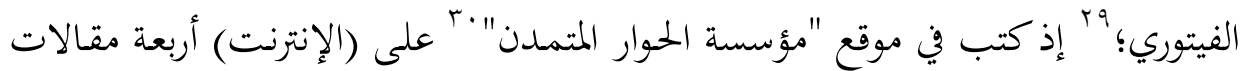

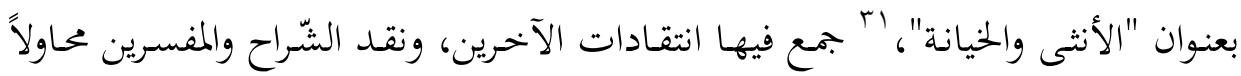
إضفاء صبغة علمية على نقده.

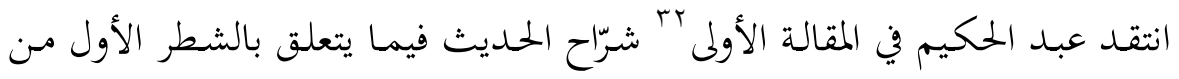

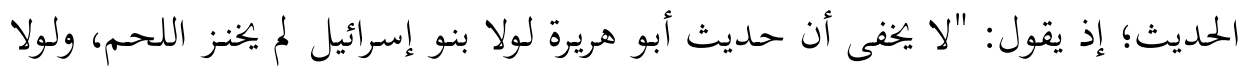

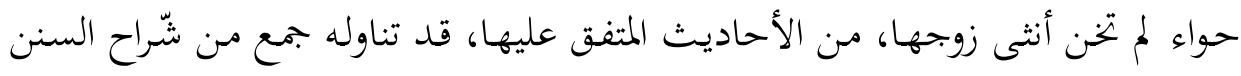

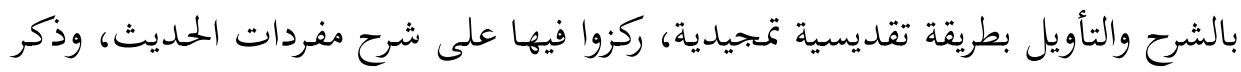
ما يستفاد من هذا الحديث من لطائف وإرشادات بنمطية كلاسيكية ذكورية. فمثلا هذا

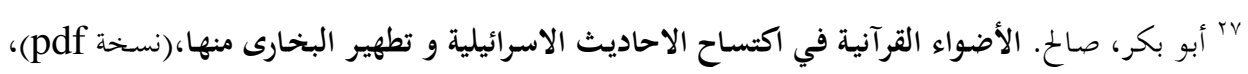

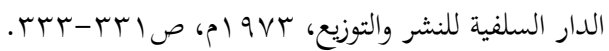

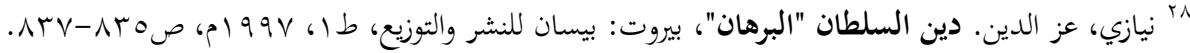

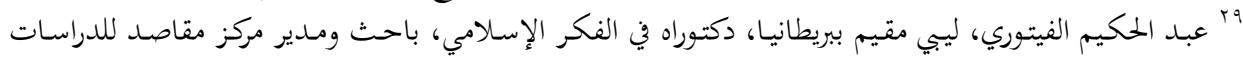

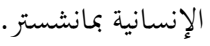

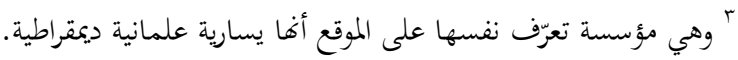
http://Www.ahewar.org/debat/show.art.asp?aid=166475 Tr http://www.ahewar.org/debat/show.art.asp?aid=166475 
الحـافظ ابـن حجـر شـارح صـحيح البخـاري في كتابـه فـتح البـاري، قـال في شـحهه لهـا الحديث: قوله لولا بنو إسرائيل لم يخنز اللحمى -يخنز بفتح أوله وسكون الخناء وكسر النون

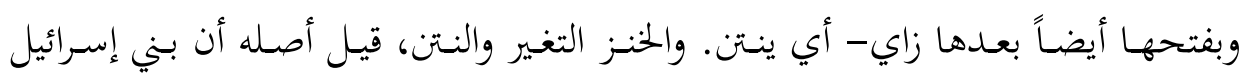

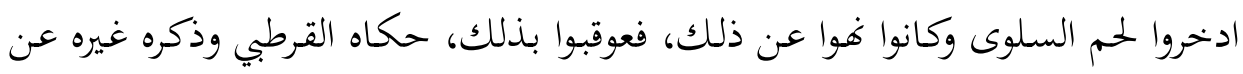

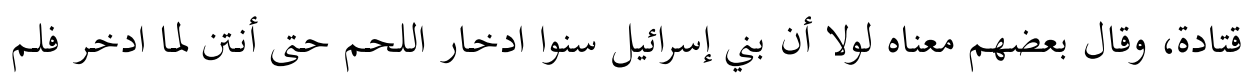

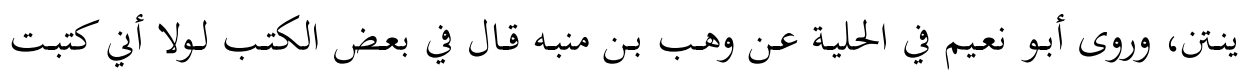

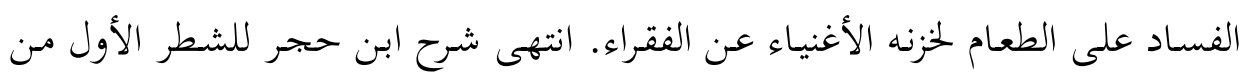

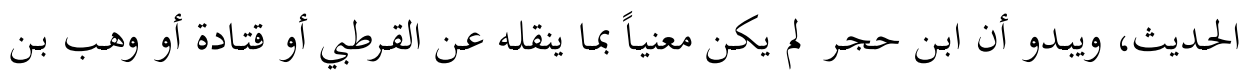

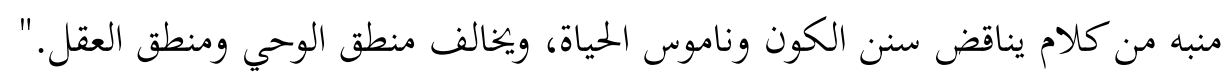
ويقول في تعليقه على ابن حجر في شرحه للشطر الثاني للحـديث: "تثم انتقل ابن

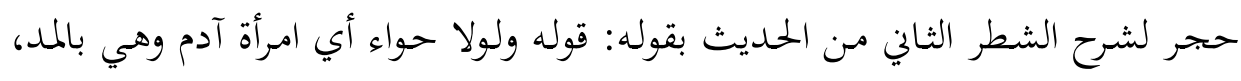

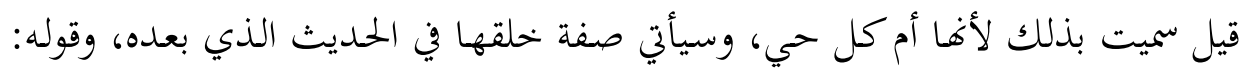

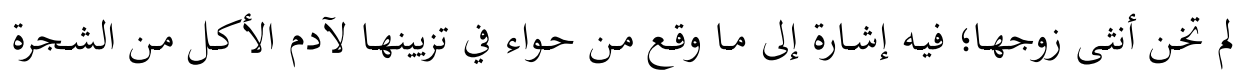

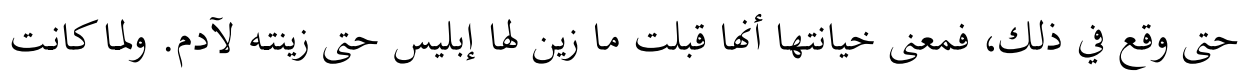

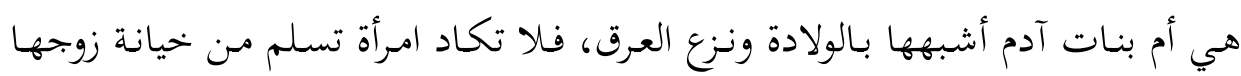

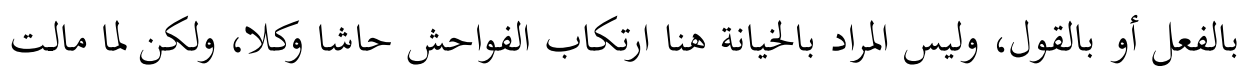

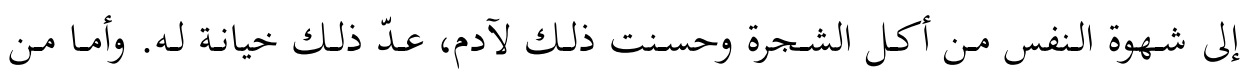

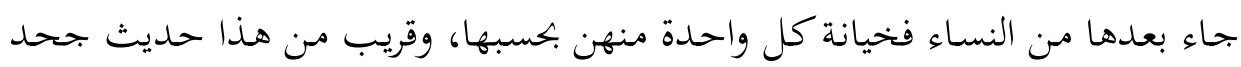

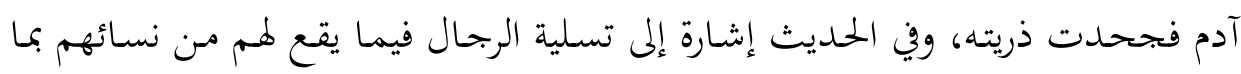

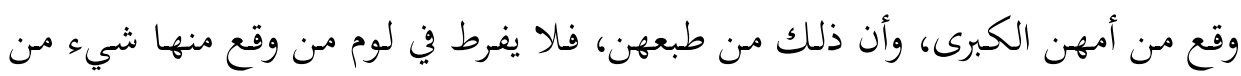

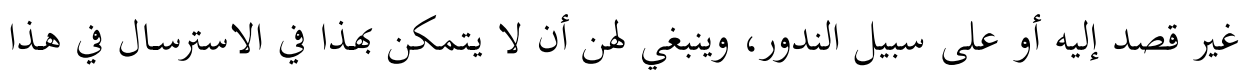

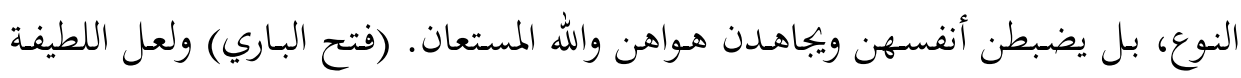

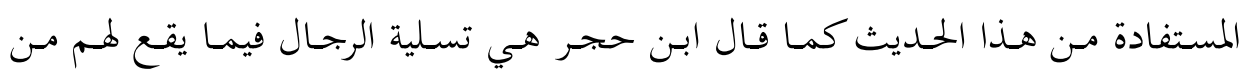

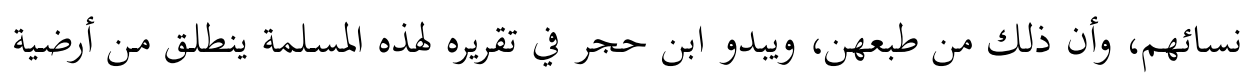


تلك الروايات الذكورية المخالفة للقرآن وقصديته، والمناقضة لمنطق العقل والواقع؛ كرواية المرأة خلقت من ضلع أعوج، ورواية النساء ناقصات عقل ودين وهلم جرا." ثم انتقـد الكاتـب النـووي في شـرحه الحـديث عنــ مسـلم، فيقـول: "ولم يبعـد شـارح

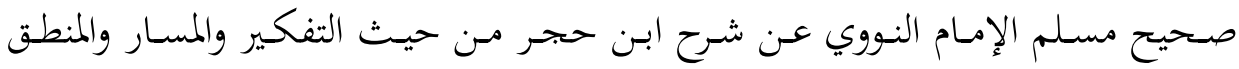

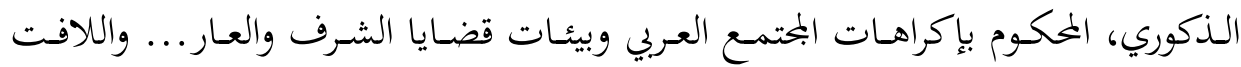

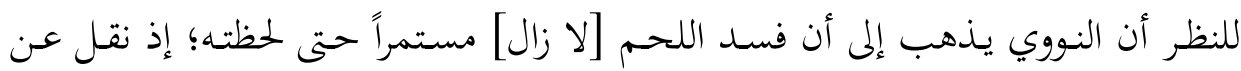

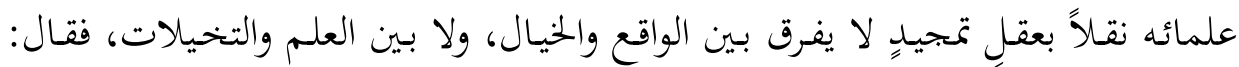

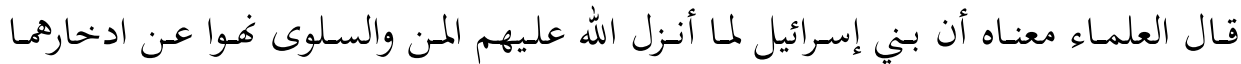

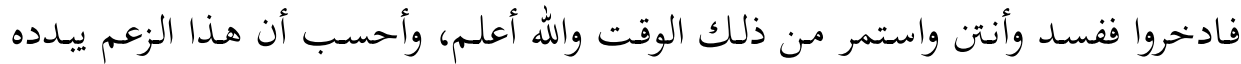
الواقع جملة، ولعل النووي في ذلك قد تخيل اللحوم في زمانه بأها فاسدة، وذلك من بـاب إقناع العقل بمنطق هذه الرواية المخالفة للوحي والعقل والواقع!!" وبعــ ذلـك ينتقـل في المقالـة الثانيـة لانتقـاد المفسـرين؛ إذ يقـول في مقدمـة المقالـة: "ينبي التنبيه هنا بأننا لا نريد الوقوف عند الشطر الأول من الحمديث (لولا بنو إسرائيل

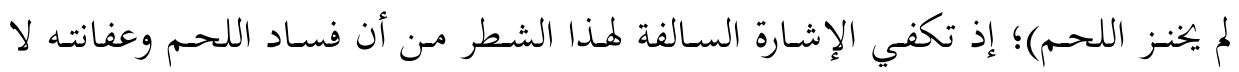

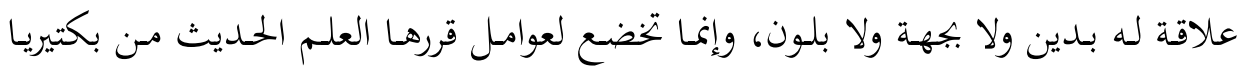
وفيروسات وغير ذلك مما هو مقرر عند علماء العلوم الحديثة، ولعل شطر هذه الرواية منتج من منتجات العنصرية الدينية والملّيّة؛ لأن رائحة التدافع الملّي بين المسلمين وغيرهم خاصة اليهود واضحة وجلية فيه، والذي يهمنا في هذا المقام الوقوف عند الشطر الثاني من الرواية (لولا حواء لم تخن أنثى زوجها الدهر) بغية معرفة حجم اعتداءات المفسر على النظم القرآي لصالح هذه الرواية، وما أفرزه من ثنقافة ذكورية تحتقر الأنثى وتزدريها بمنطق الـدين والإيمـان، لدرجـة اقتنـاع الأنثى ذاهـا بتلـك الثقافـة الذكوريـة (العنصـرية الذكوريـة) المخالفة لمنطق الوحي وقصديته، فنأخذ لذلك عينة تفسيرية تثبت مـدى الترابط بين ما قاله المفسر في القـديم، ومـا نقله عـن المفسر الحـديث عنه، على الرغم مـن تغير السياق 
التاريخي والمساق الثقافي والاجتماعي، وذلك من خلال تفسير ابن جرير الطبري وتفسير

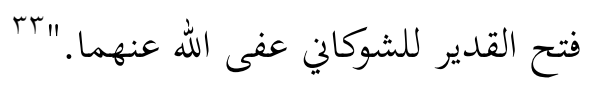
تم ينقل بعبارات فيها الكثير من الازدراء كلام الطبري في تفسير آيات سورة البقرة

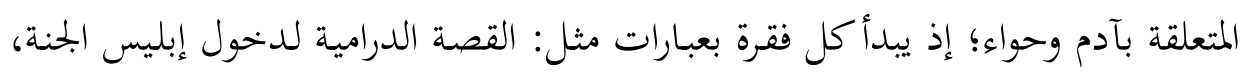

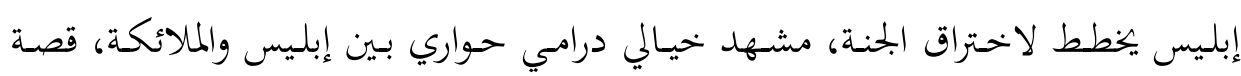

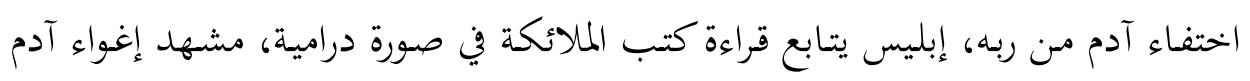

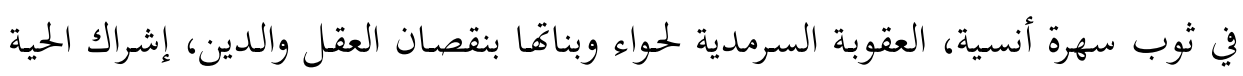
في عقوبة حواء.

ثم ينتقـل إلى الشـوكاني في فتح القـدير فيقول: "لخص الشـوكاني مـا قاله ابـن جريـر الطبري بزيادة بعض الأسانيد والمتون الأسطورية، فقال في تفسيره فتح القدير: وقد أخدرج

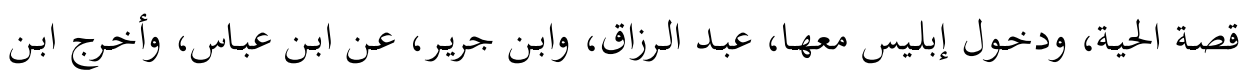

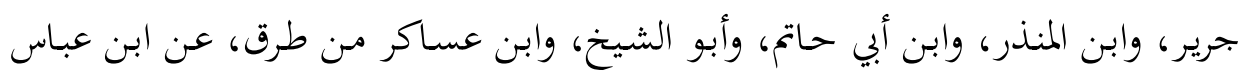

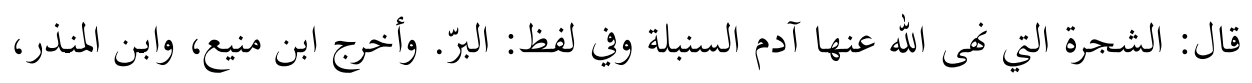
وأبو الشيخ، والحاكم وصححه، والبيهقي في الشعب، عن ابن عباس قال: قال الله لآدم:

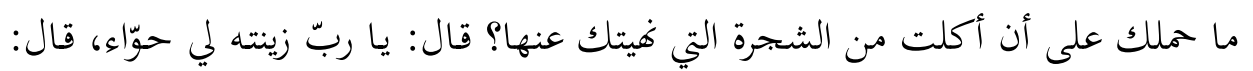

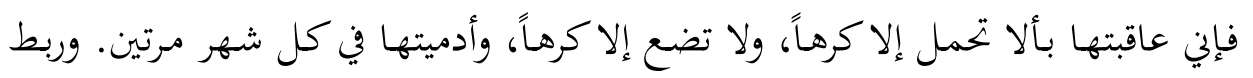

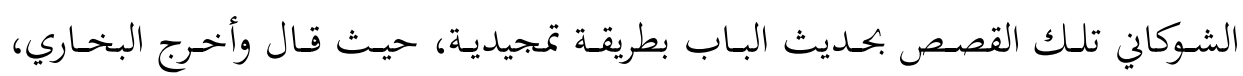

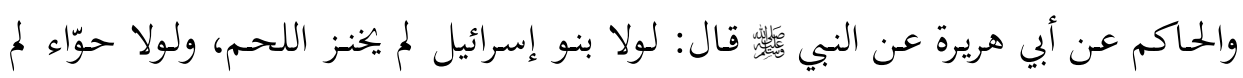

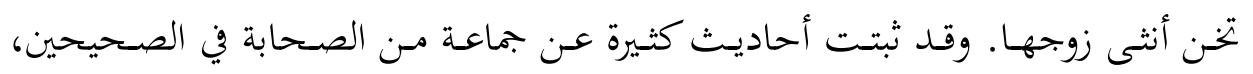

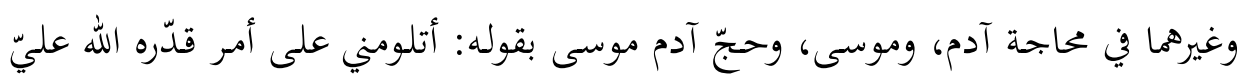

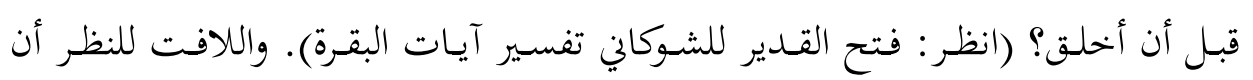

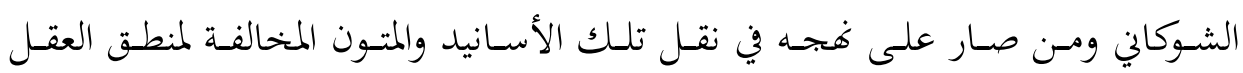

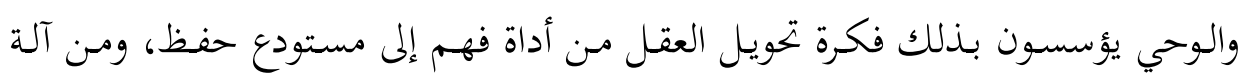


استكشاف إلى آلة استذكار، كذلك ينشرون ثقافة العنصرية الذكوريـة باسم الدين التي

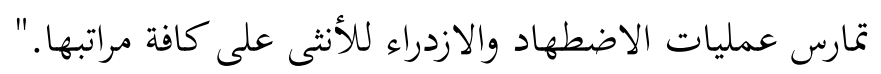
ووفي المقالة الثالثة يذكر نصوصاً من الكتب المقدسة يبين من خلالفا أها مصدر هذا

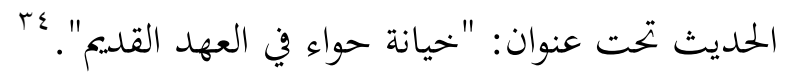

ووفي المقالة الرابعة بمهاكم مفردات الحديث، مستشهداً بإحصائيات تقول إن الواقع يكشف عن أن نسبة الخيانة عند الرجال تفوق نسبتها عند الإناث، والعقل الكلاسيكي

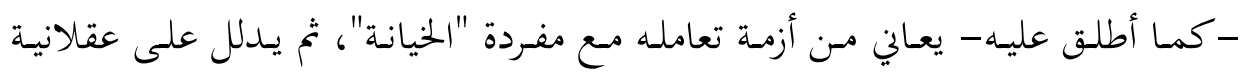

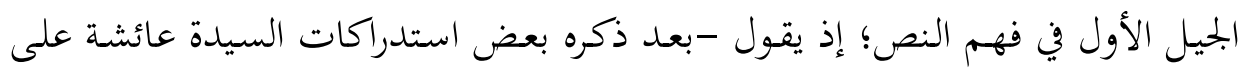
الصحابة-: "يبدو أن ميزان السيدة عائشة في قبول الرواية جد محكم، فما خحالف قصدية القرآن ومنطق العقل رفضته وإن كان القائل به جمهور الناس، فالعبرة عندها ليست كثرة

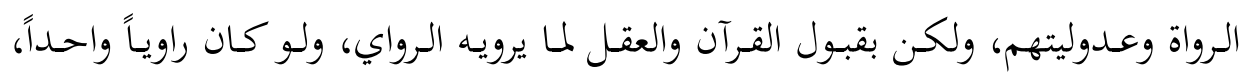
وبذات الميزان والمنهج (العائشي) يمكننا وزن حديث أبي هريرة: لولا بنو إسرائيل لم يخنز اللحم، ولولا حواء لم تخن أنثى زوجها. والقول فيه بأنه حديث لا يستقيم ومنطق الوحي

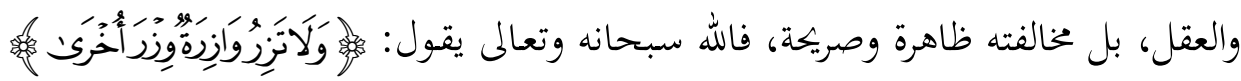

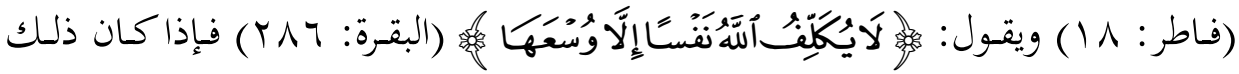

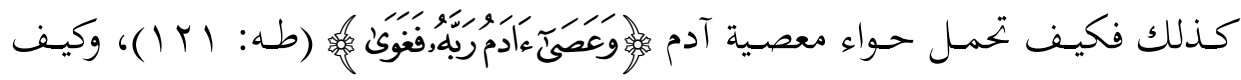
تعاقـب بنـات حسواء بـالحيض والنفـاس، والكـره في الحمـل والوضـع، وكيف تصـبغ الأنثى

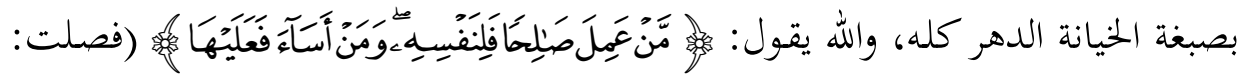

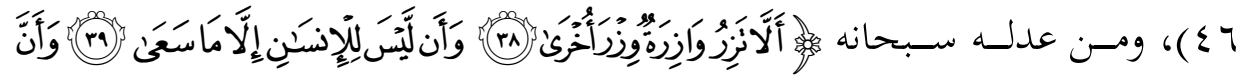

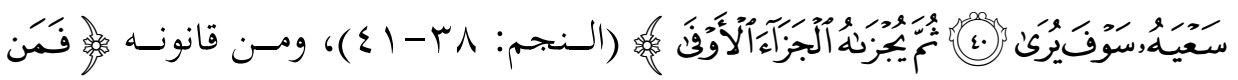

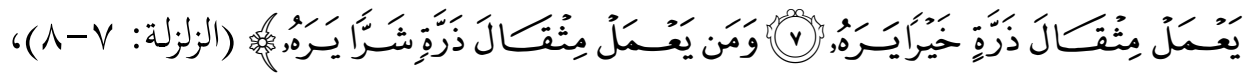

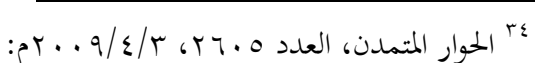
http://www.ahewar.org/debat/show.art.asp?aid=167797 Pro http://www.ahewar.org/debat/show.art.asp?aid=168423 


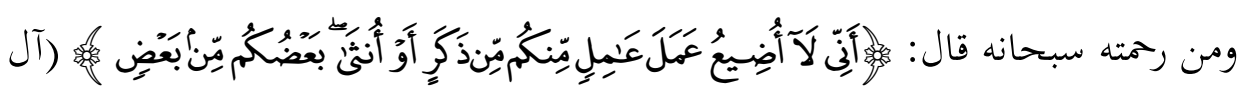

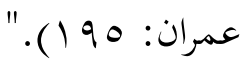

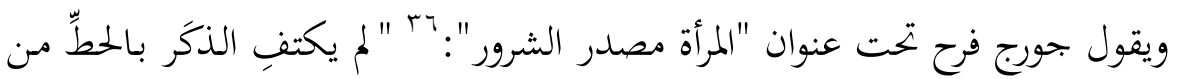

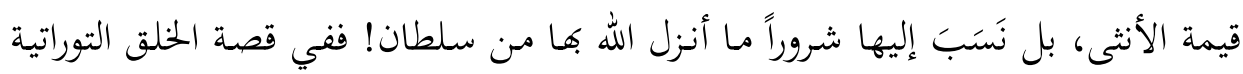

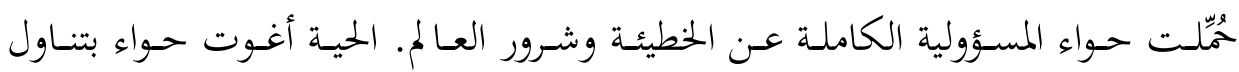

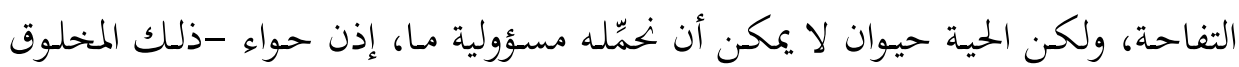

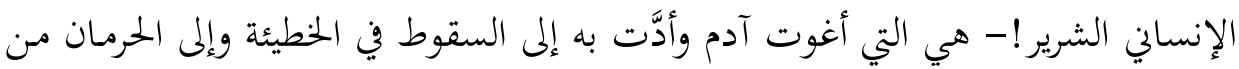

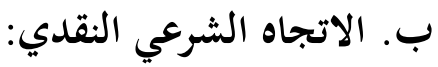

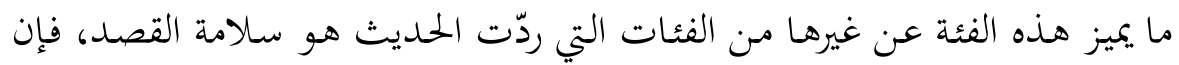

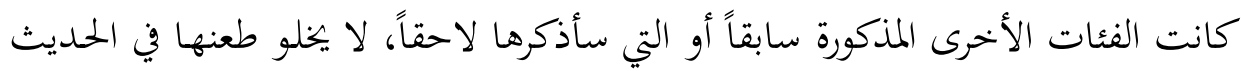

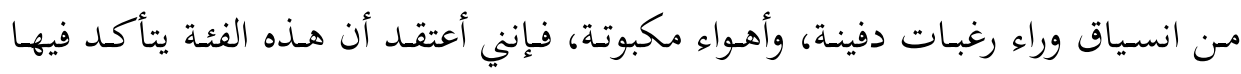

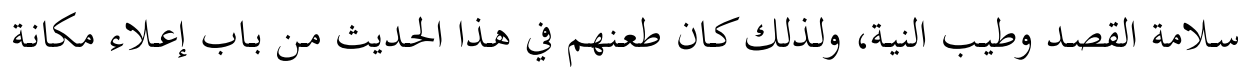

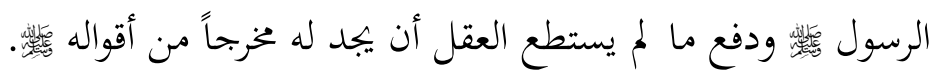
ومسن أوائل مـن وقفت على كلامـه مـن علماء الأمـة الإمام محمد الغزالي في كتابه:

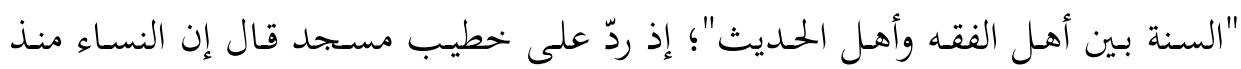

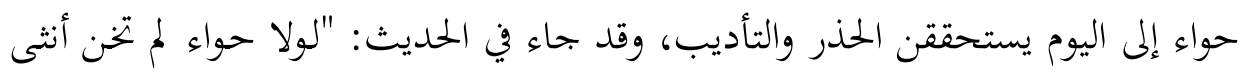

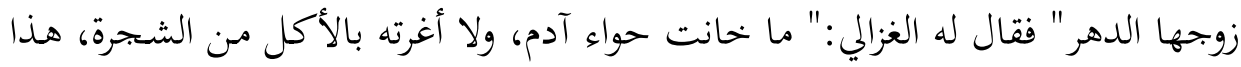

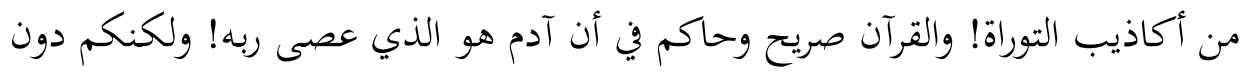

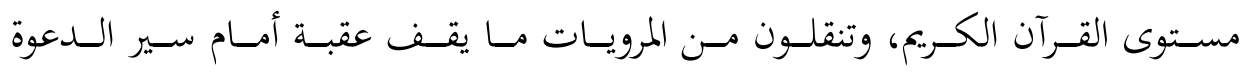

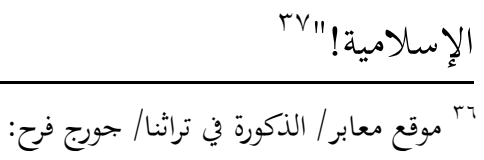

http://www.maaber.org/eighth_issue/malehood_in_our_tradition.htm

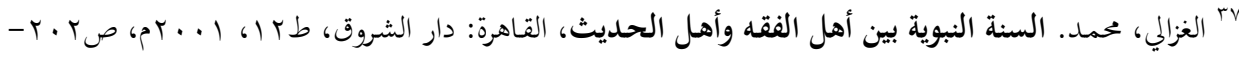


وتابعه العلامة يوسف القرضاوي في لقاء تلفزيوني على قناة الجزيرة عندما سئل عن

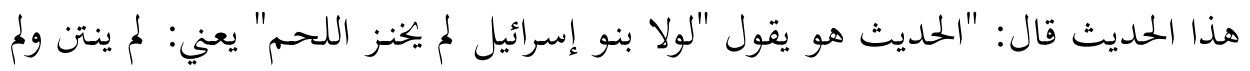

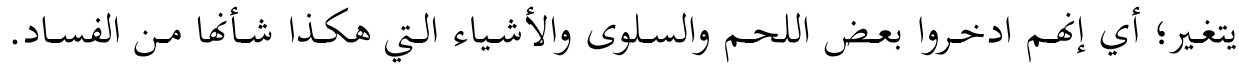
فكان أن ابتلاهم الله تعالى بإنتان اللحمم، وهو قانون طبيعي في الأشياء، وسنة من سنن

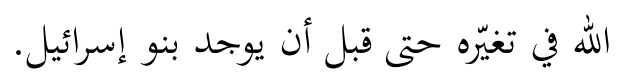
وقوله: "ولولا حواء لم تخن أنثى زوجها" لا يعني أن حواء خانت زوجها، فهذا ليس

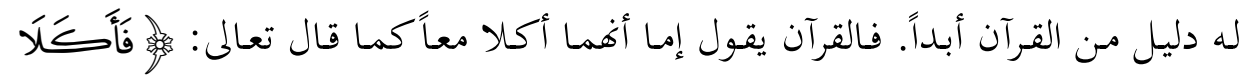

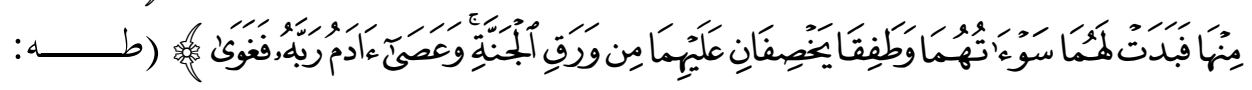

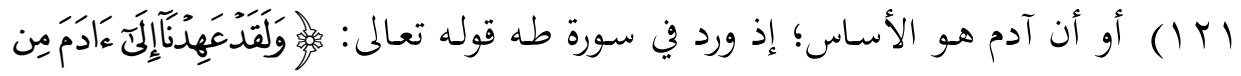

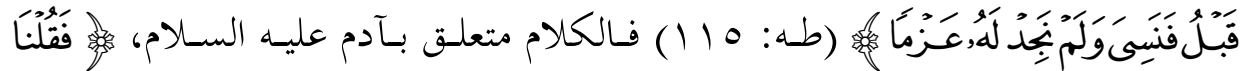

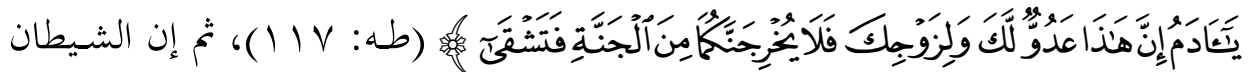

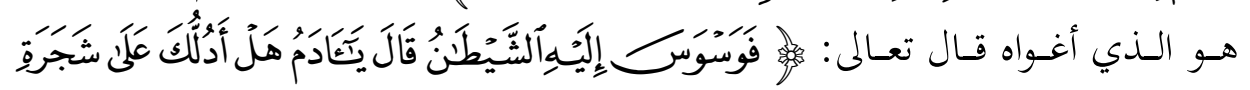

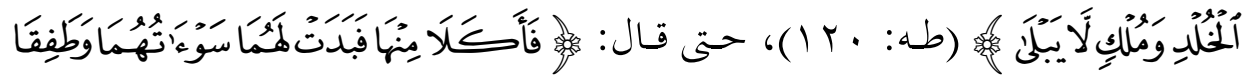

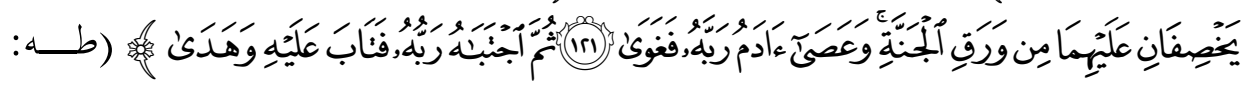

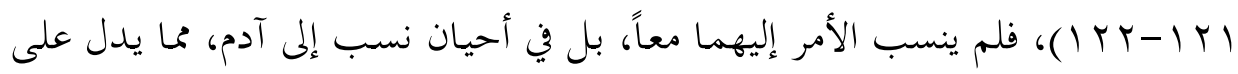

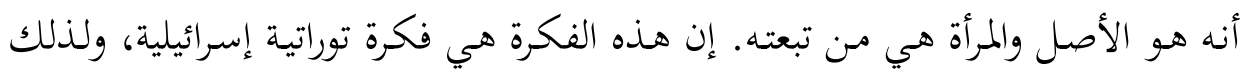

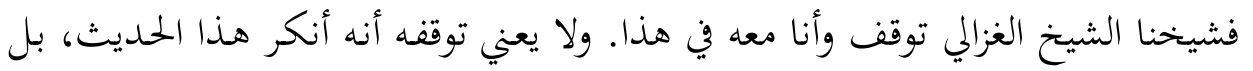

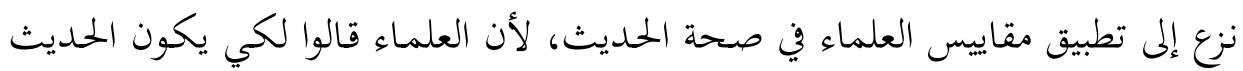

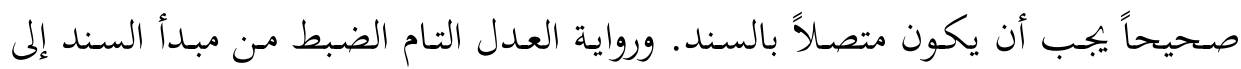

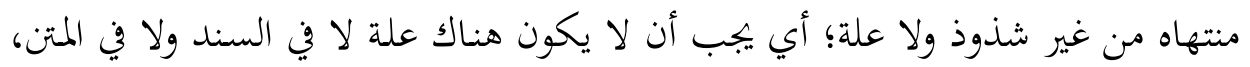

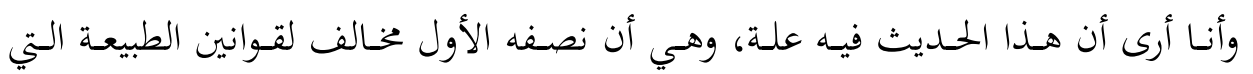

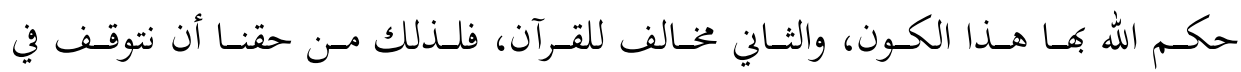
قبوله.

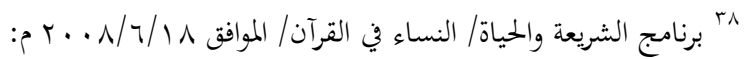
http://www.aljazeera.net/channel/archive/archive?ArchiveId=1098789 
وومن المعاصـرين أيضـاً الـدكتور محمــ سـعيد حسوى في مقالـة لـه في جريـدة الـرأي

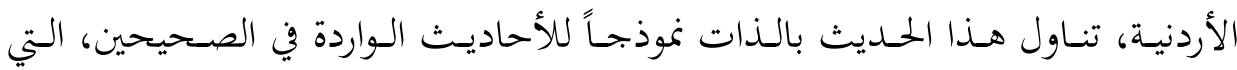

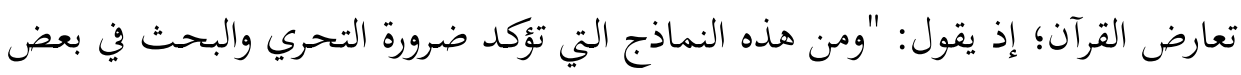

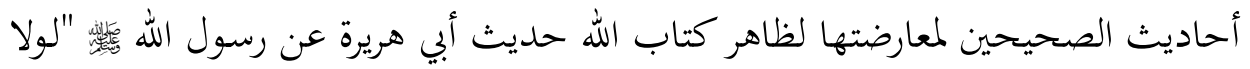

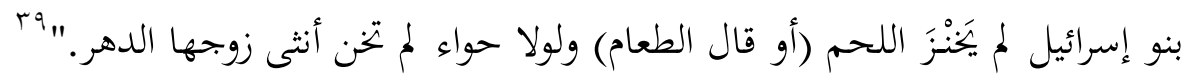
وبعد أن أثبت صحة السند توجه للمتن فقال: "أما متناً: فالحديث يصادم ويخالف

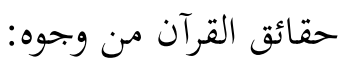

ا ـ قضــية خيانـة حسواء: إن التـوراة المحرفـة هـي التي تقـرر أن سـبب وقـوع آدم في

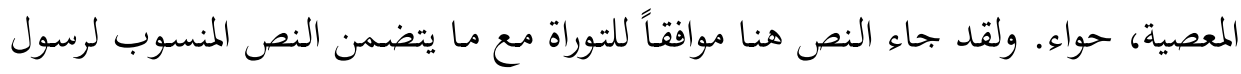

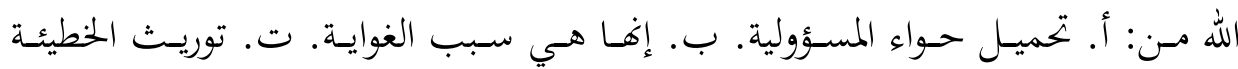

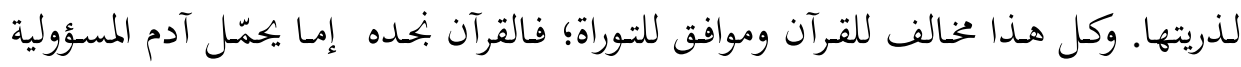

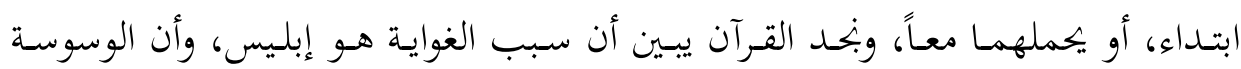

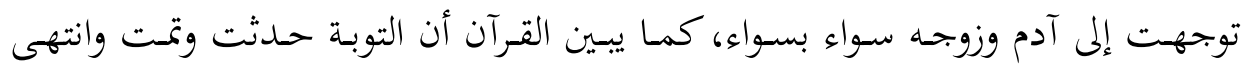

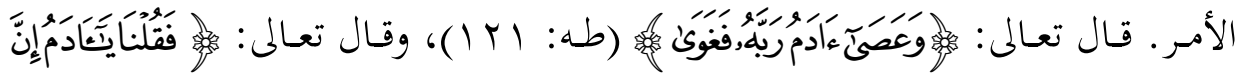

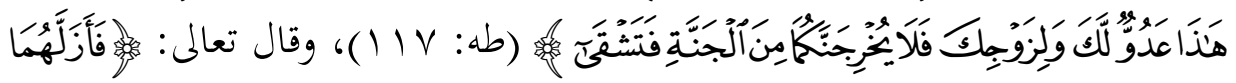

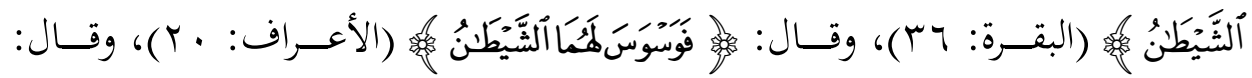

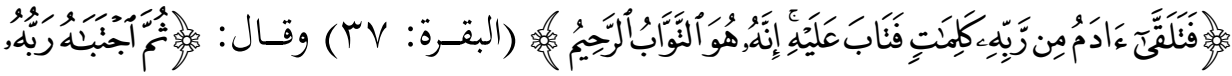

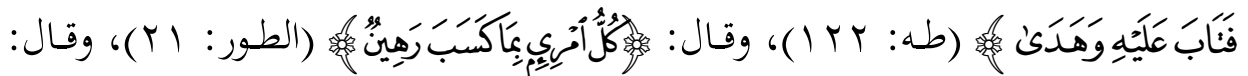

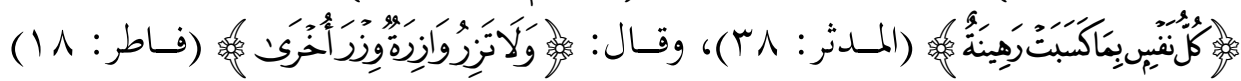
إضافة إلى الآيات الكثيرة التي تتحدث عن مكانة المرأة وسمو العلاقة الزوجية. وبعد: فإن كل حقائق القرآن تأبى أن تحمل حواء مسؤولية الغواية أو الخيانة، أو إنها

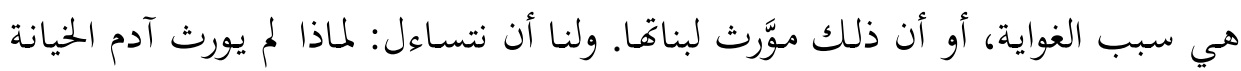

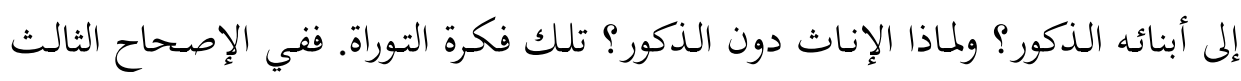

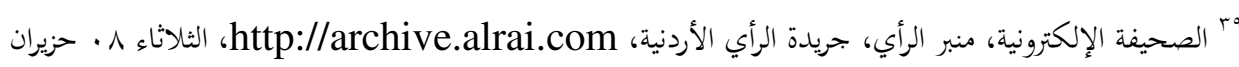




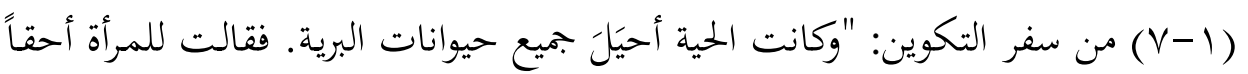

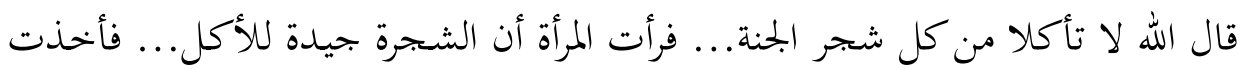

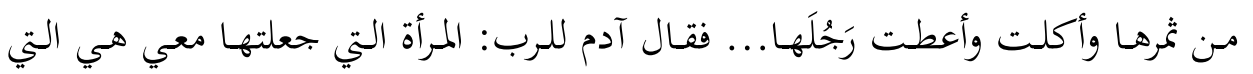

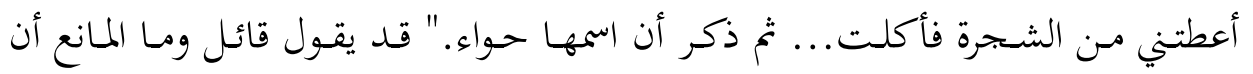

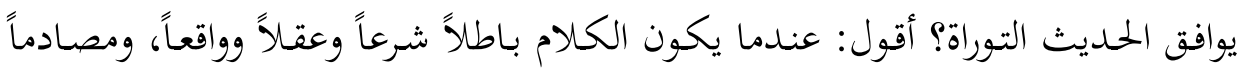
للقرآن، فلا يجوز أن نسأل هذا السؤل ألمال.

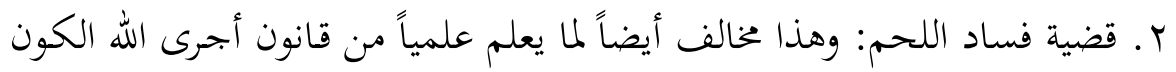

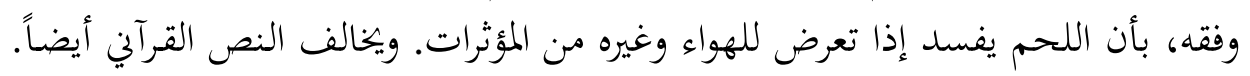

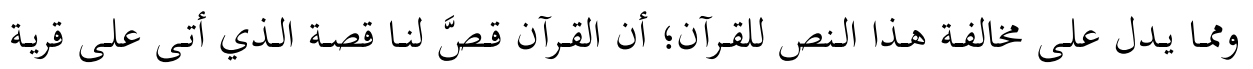

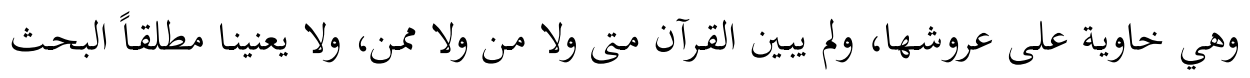

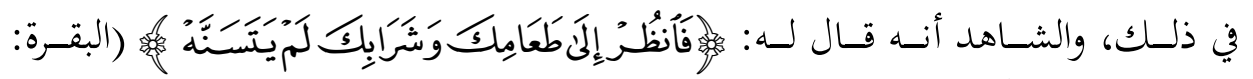

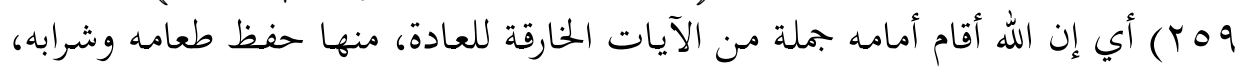

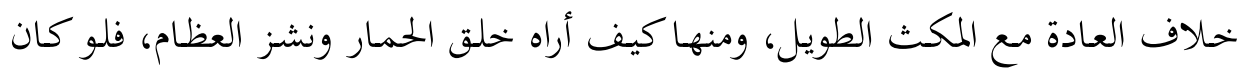

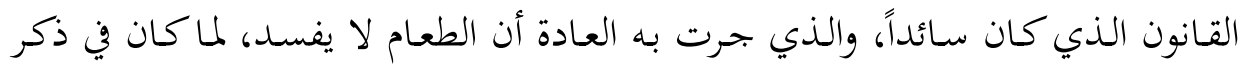

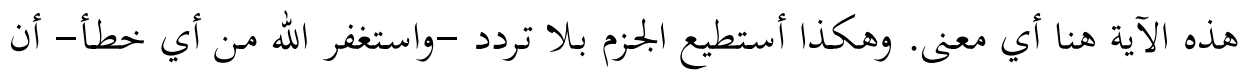

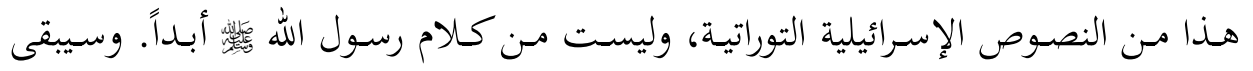

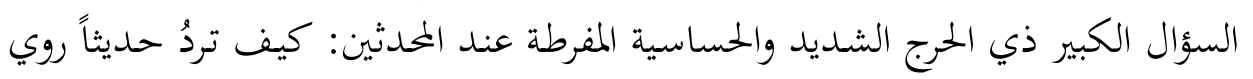

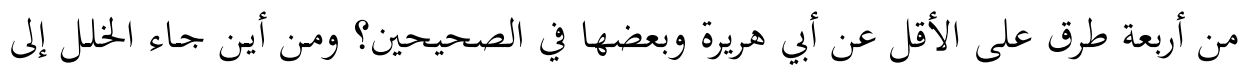

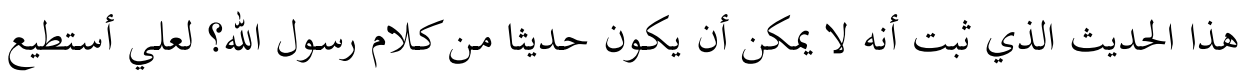

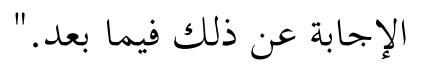

\section{r. موقف من استغل الحديث للطعن بالإسلام أو الرسول أو السُنة:}

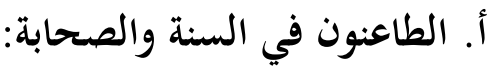

لقد تناولت الشيعة في مواقتهم أيضاً الحديث بنوع من السخرية والاستهزاء حيناً،

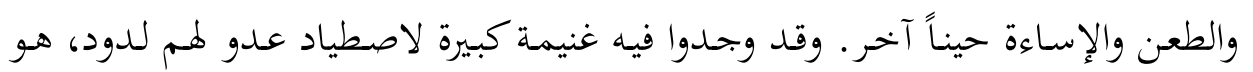

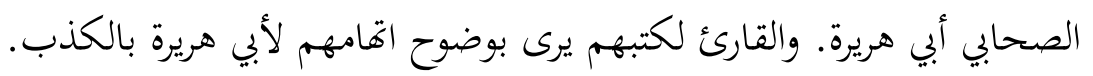


ففي موقع شمس كربلاء يذكر الحديث تحت عنوان "البخاري ومسلم يتفقان على

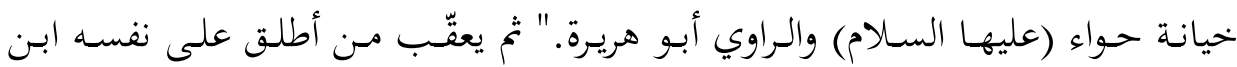
الزهراء فيقول: "فليتفضل أحد عقلاء السنة وليوضح كيف أن حواء أم البشر (خائنة)، وذلك لأن لفظ الخيانة إنما يؤخذ عند الإناث في العرف اللغوي السائد خيانة شرفية

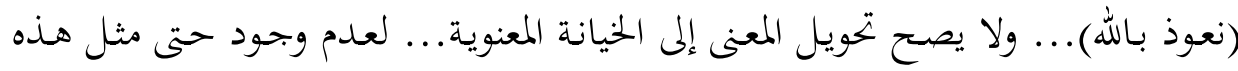

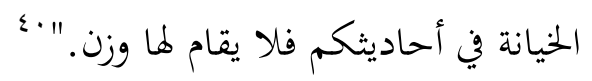

وفي موقع رسول الله وأهل البيت تحت عنوان "صحيح مسلم يتهم زوجة النبي وكل

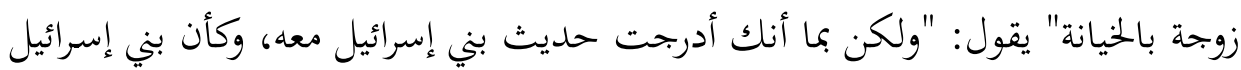

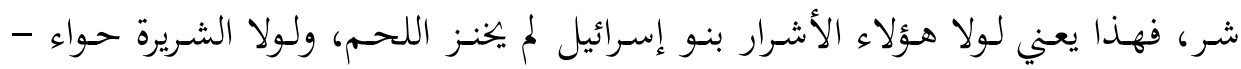

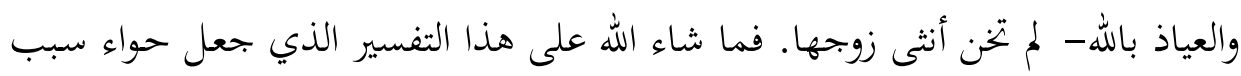

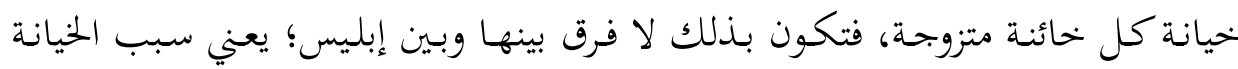

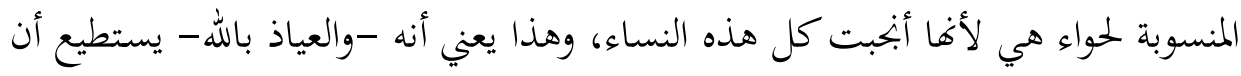

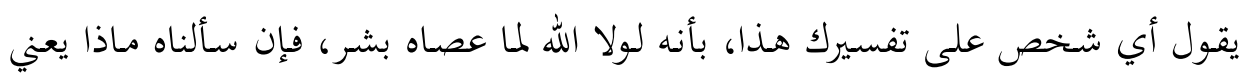

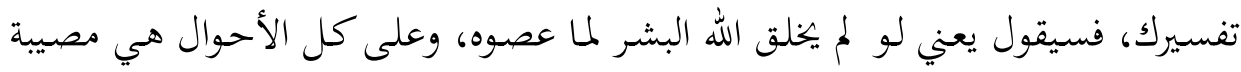

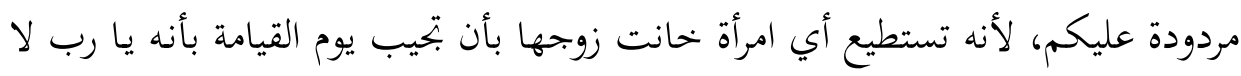

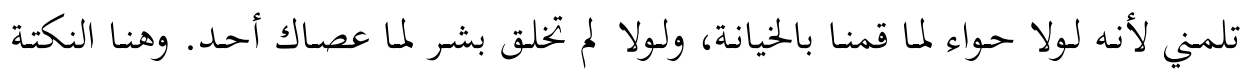

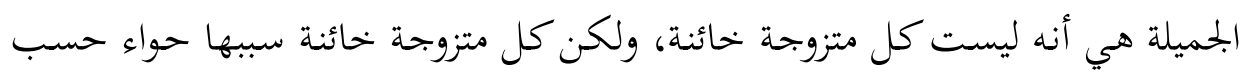

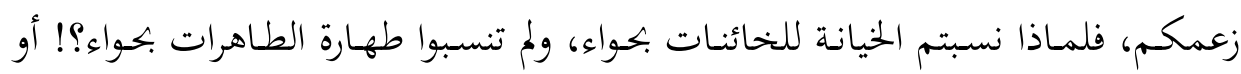

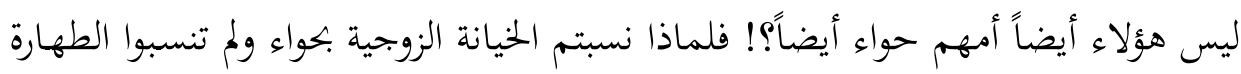

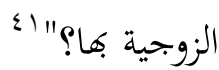
" موقع شمس كربلاء/المنبر العقائدي:

http://www.shmskrbla.com/vb/showthread.php?t=18832 " شبكة ومنتديات فداك رسول الله وأهل البيت عليهم السلام "المنتديات الحوارية والعقائدية" المنتدى الحواري 
وفي موقع شبكة أنصار الحسـين -عليه السلام- يـذكر الحـديث تحت عندوان "لولا

حواء لم تخن أنثى زوجها المصدر البخاري ومسلم!" ثم يقول: "أكانت أمنا حواء خائنة؟!

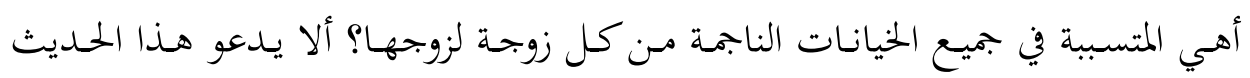

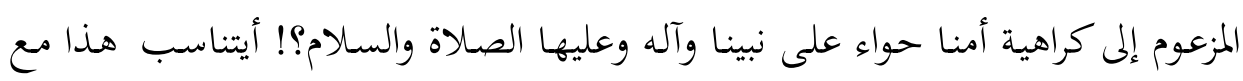

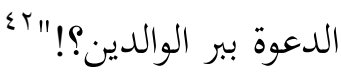

\section{ب. الطاعنون في الرسول والرسالة:}

لم أكن أتوقع أن يُهاجم هـذا الحـديث مـن النصارى؛ لأن الكتـاب المقـدس عندهم

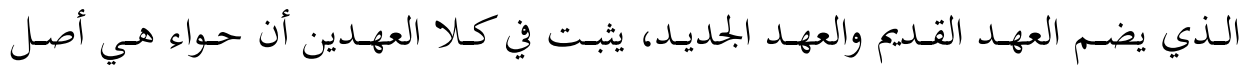

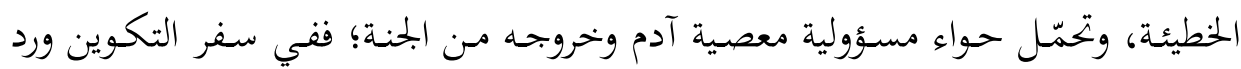

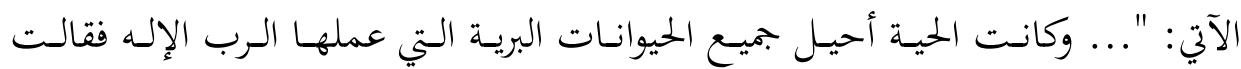

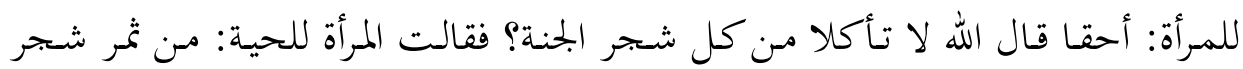
الجنة نأكل، وأما ثمر الشجرة التي في وسط الجنة فقد قال الإله: لا تأكلا منه ولا تمساه

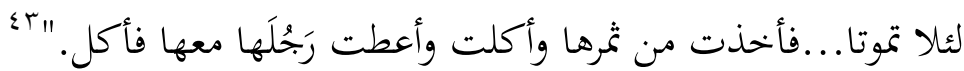

ويقول بولس: "وآدم لم يغو، لكن المرأة أغوت فحصلت في التعدي، لذلك لم يأذن لها الرسول أن تعلم، ولا أن تتسلط على الرجل، بل تكون في سكوت لأن آدم جُبِل أولاً

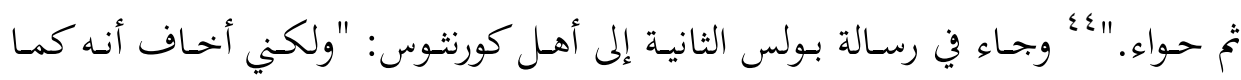

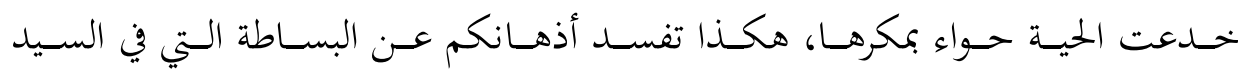
०11 المسيح

ومع ما ذكرت بندهم في مواقعهم يتناولون هذا الحديث بالطعن. وقبل أن أبدأ بنقل أقوالهم أقول: لقد اتفقت كلمة العلماء أن ناقل الكفر ليس بكافر، وأنـا أبرأ إلى الله مئا

http://www.r-ahlulbait.com/a/showthread.php?t=1742 ${ }^{42} \mathrm{http}: / /$ www.ansarh.com/forum/showthread.php

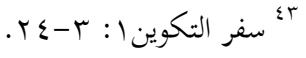

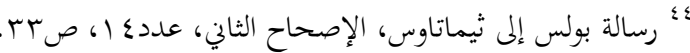

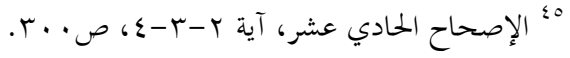


يقولون، لكـن للأمانـة وللوقوف على كل مسن انتقــ الحـديث أراين مكرهـة على نقـل كالעمهم.

ففي موقع (الأقباط) منتدى منظمة أقباط الولايات المتحدة تحت سلسلة (من هو الكذاب) وبعنوان "لولا اليهود لما وجدت البكاط) ولمتيريا، ولولا حواء لما خحانت النساء" "سلام

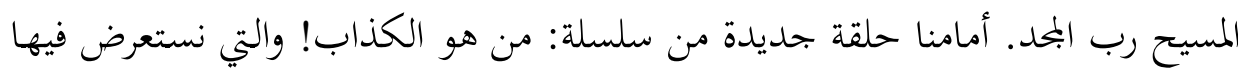

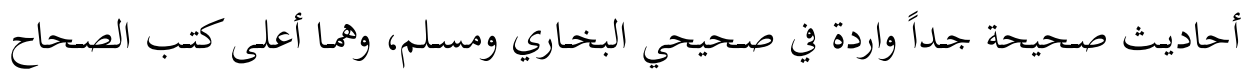

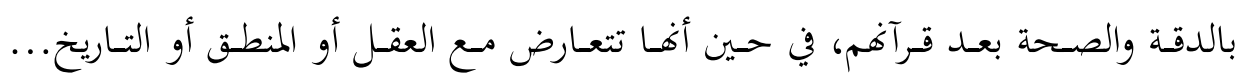

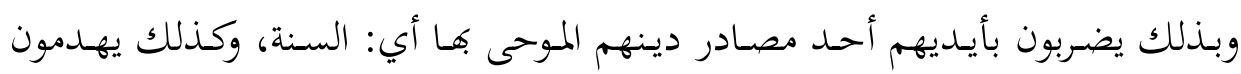

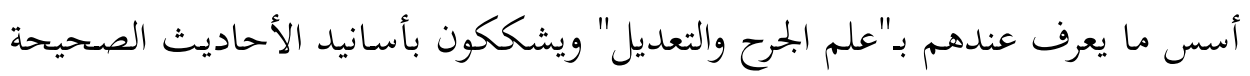

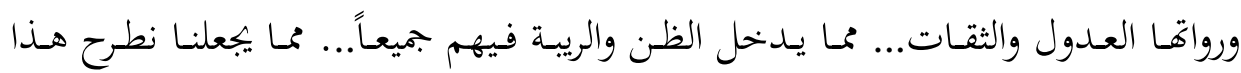

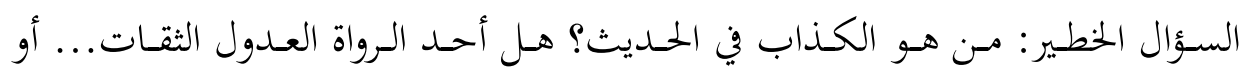
الصحابي أو محمد نفسه؟ الصوير: من هو

واليوم نعرض لمسألة جديدة طرحها محمد في حديثه الصحيح الذي أورده البخاري في صحيحه، وكذلك مسلم! وها هو الحديث (ويذكر حديث البحث) ونقول للبيان:

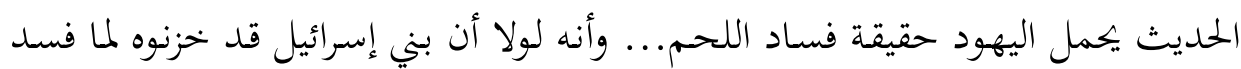

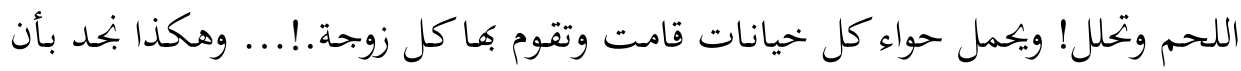

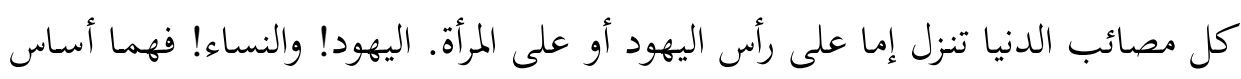

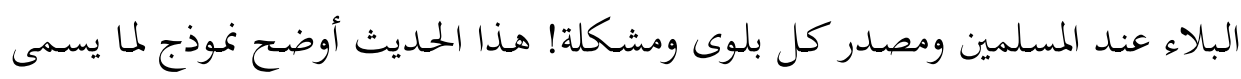
بـ"نظرية المؤامرة"! أو مخططات بني صهيون. كما أن كل مصيبة يلقوغا على المرأة!

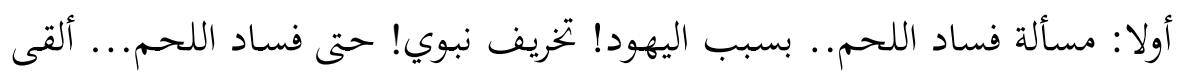

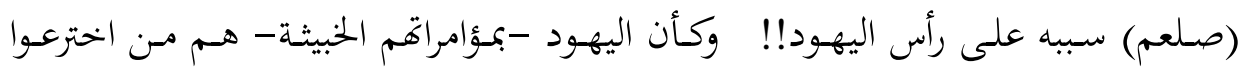

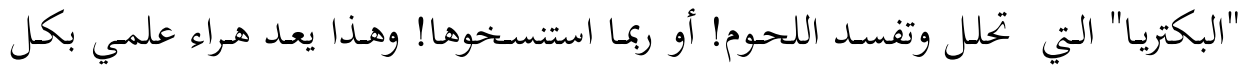

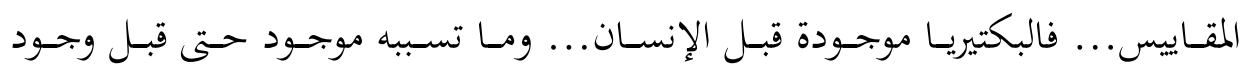

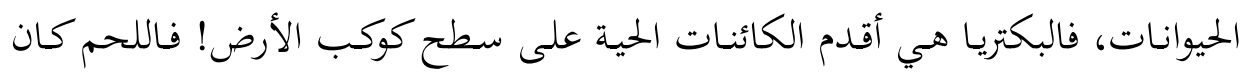

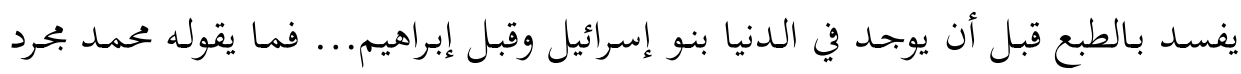


تشويش الختلط في ذهنه من جراء ما كان يسمعه متناثراً مغلوطاً من التوراة المقدسة دون

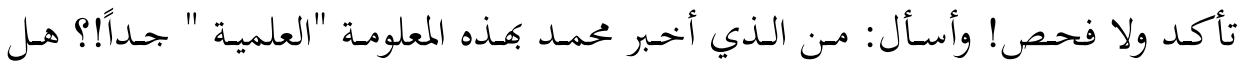

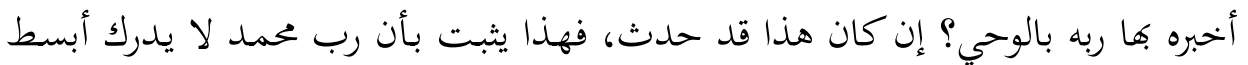

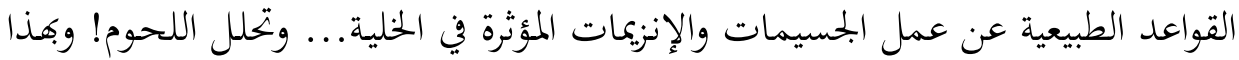

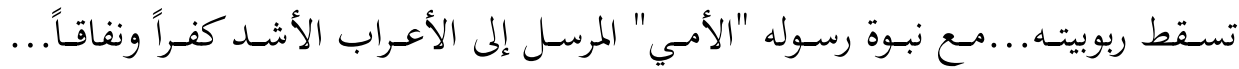

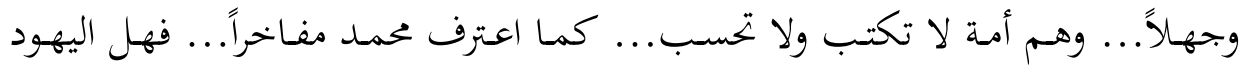

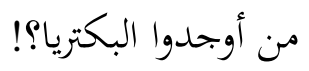

ثانياً: لولا خيانة حواء.. لكانت كل النساء شريفات! وهذا يشين جنس النساء...

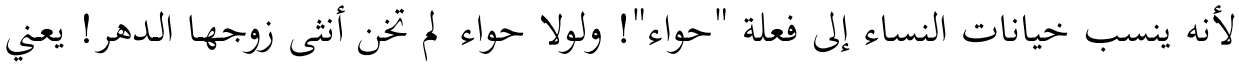

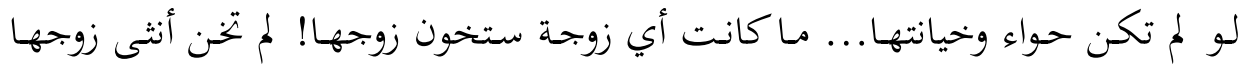

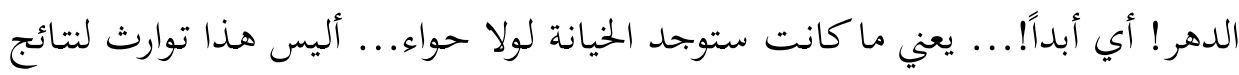

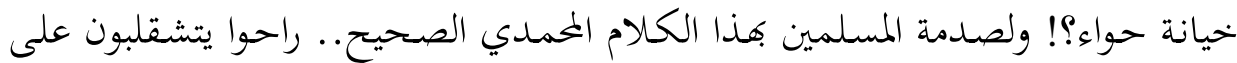

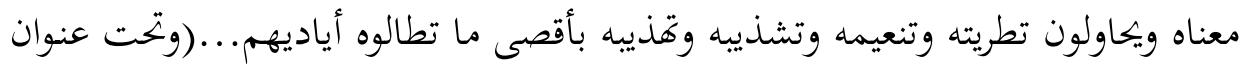

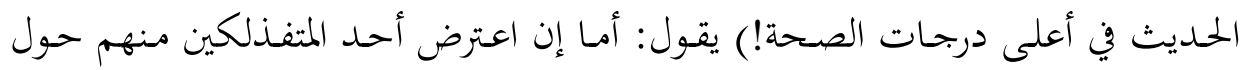

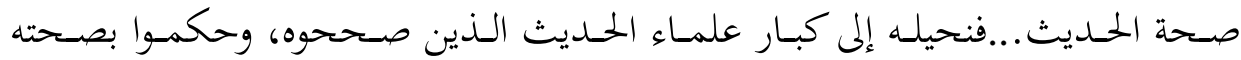

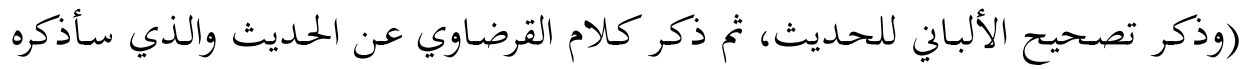

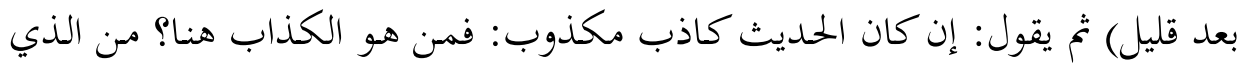

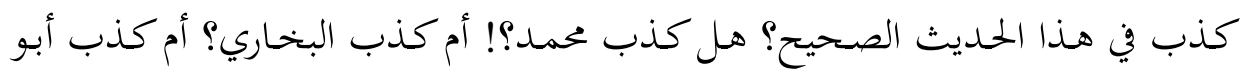

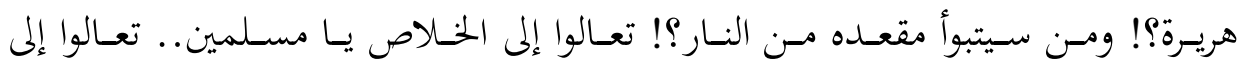
النور.

\section{رابعاً: المناقشة والترجيح}

الطعن في سند هذا الحمديث لم يكن بصورة مباشرة برواة السند، فالحمديث مروي من

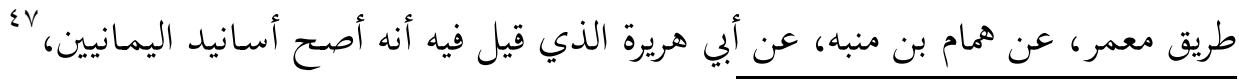
"كنتندي منظمة أقباط الولايات المتحدة "المنتدى العرى" منتدى حوارات الاديان: http://www.copts.net/forum/showthread.php?t=32374

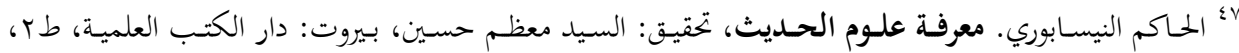

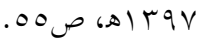




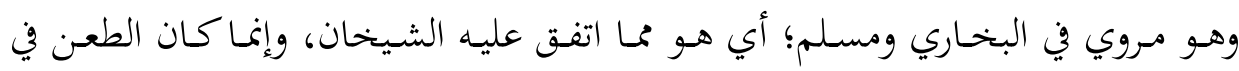

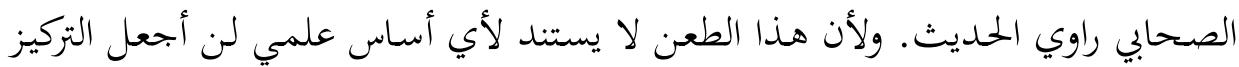

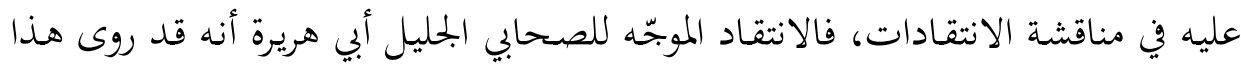

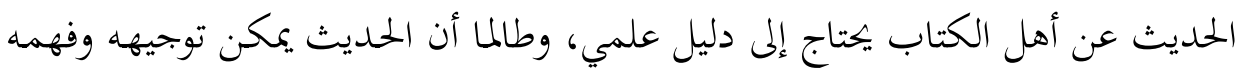

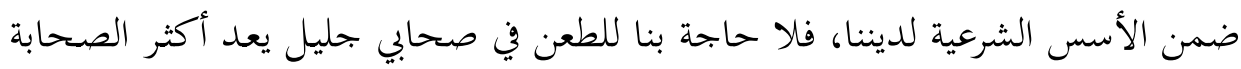
رواية للحديث.

أما الطعن في مـن الحديث فقد نال نصيب الأسد من المغرضين ومـن المنافحين عن الدين، وقد تصدى للرد على الطعون أساتذة فضلاء. ومن أهم ما وقفت عليه من ردمن ردود

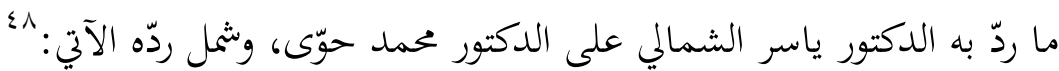
ا ـ إن هناك كثيراً من نصوص القرآن موافقة للتوراة، فهل يعني ذلك أن نرد نصوص

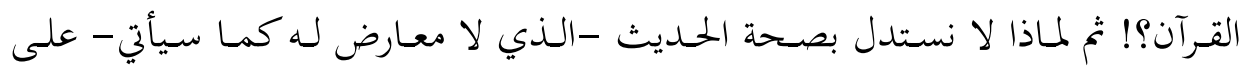

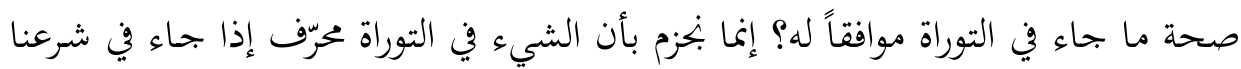
ما يصادمه أو يكذبه.

r. سـوء فهم الحـديث، وخحلل في توجيه كلام الشراح؛ إذ يقـول: "يبين ابن حجر

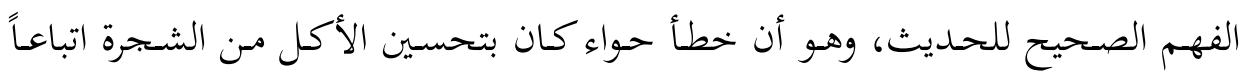

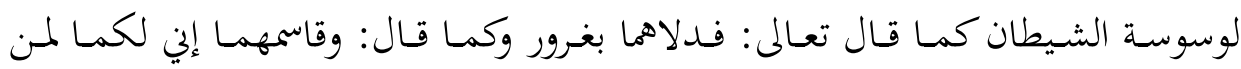

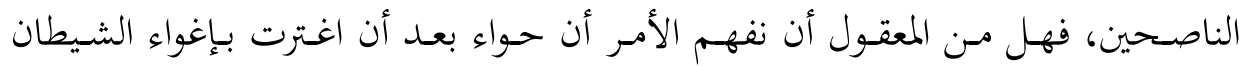

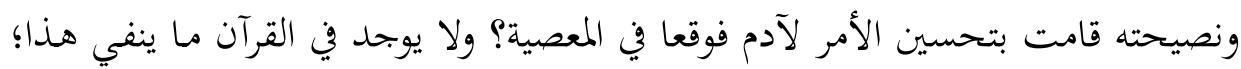

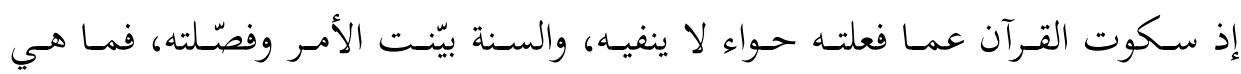

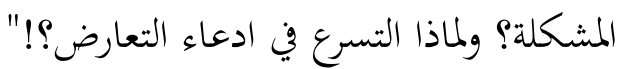

ثم يرد على الجزء الأول من الحديث فيقول في المقال ذاته: "الحديث يتكلم عن عمل

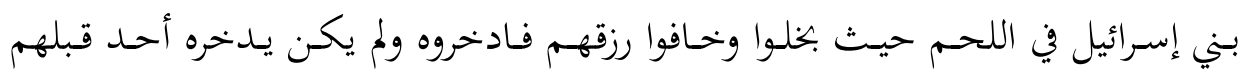

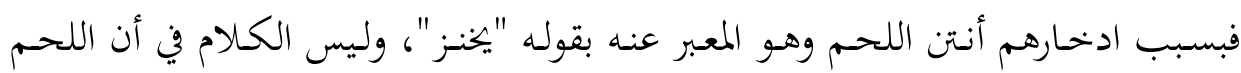


كان قبل بني إسرائيل لا يخنز، -وإن كان بعضهم فهم هذا- فلولا بنو إسرائيل لم يدخر،

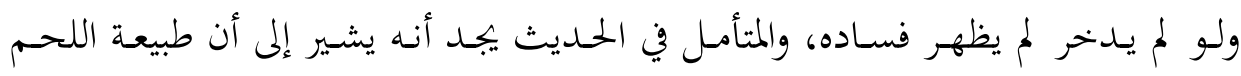

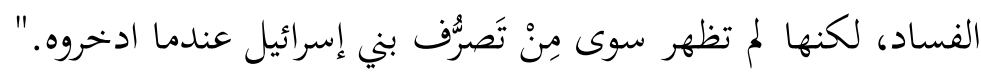
وأوافق الدكتور الشمالي فيما ذهب إليه في الشطر الأول من الحديث، وهو الكلام عن فساد اللحم؛ فالحديث يبين طبيعة من طبائع بني إسرائيل اشتهروا بها في واقع الحال، وهذه الطبيعة لم تنفك عنهم في يوم من الأيام، وهذه الطبيعة هي حبهم للمال وللكنز

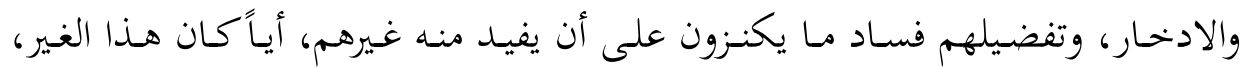

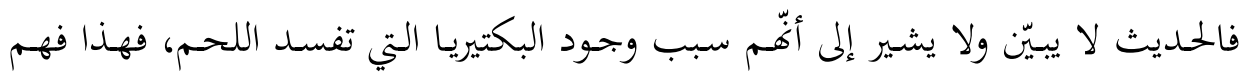
مغلوط للنص، وإنما يبيّن طبيعة اختصوا بها عن غيرهم، حتى إذهم يدّخرون ما لا يصح

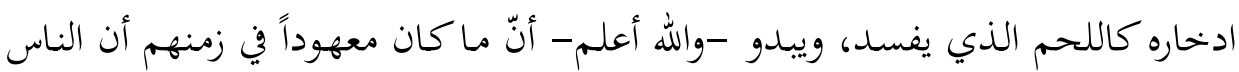
كانـت تــبح، ثم إذا زاد عـن حاجتها شيء إمـا أعطتـه للآخـرين، أو تركته للحيوانـات

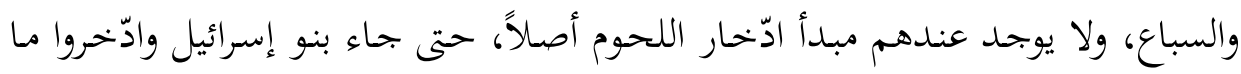

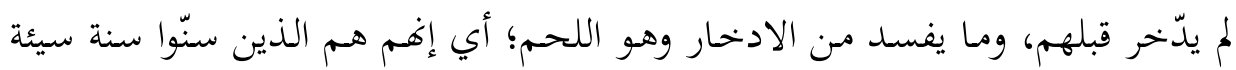
هي ادّخار اللحم وفساده، لعدم إتاحة الفرص لغيرهم للانتفاع به.

ونظرة سريعة لواقع حالنا، وما نعايشه نحن بالذات من تاريخ طويل مع هؤلاء، بند

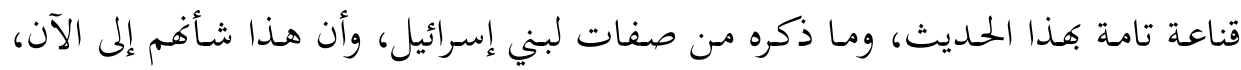
ففساد ونتن ما لا يحتاجونه مما ينتفع به غيرهم، أحب إليهم من أن ينتفع به غيرهم، والله وله أعلم.

ولعلي أقول إن الأساس في الرد على هذه الطعون جميعها يكون بالرد على الأساس

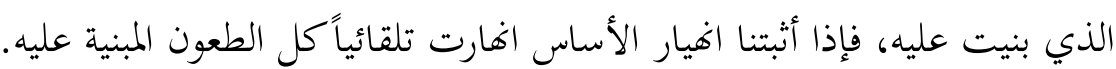
إنّ أساس هذه الطعون هو النظر إلى الحميث بعين الشّراح والمفسرين؛ إذ بنيت كل

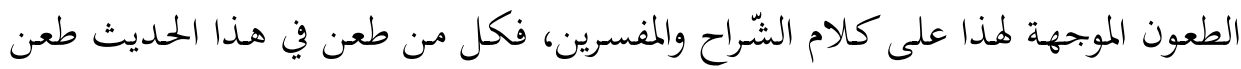

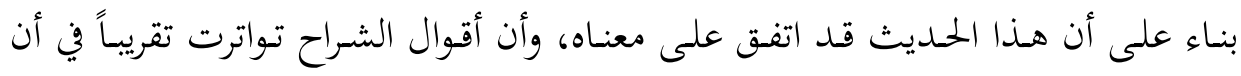


المراد منه خـروج آدم وحسواء مـن الجنـة، ومثاله شرح ابن حجر -وهـو أفضـل مـن شرح

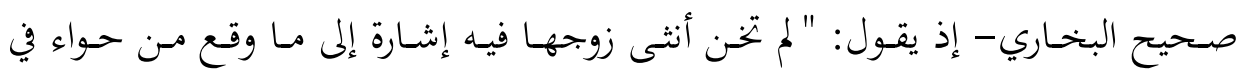
تزيينها لآدم الأكل من الشجرة حتى وقع في ذلك؛ فمعنى خيانتها أها قبلت ما زين لها لها

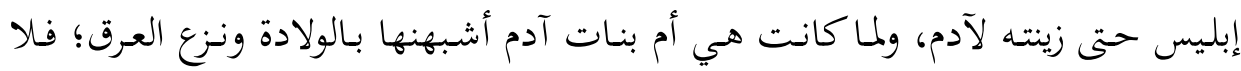

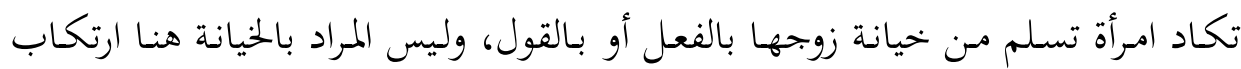

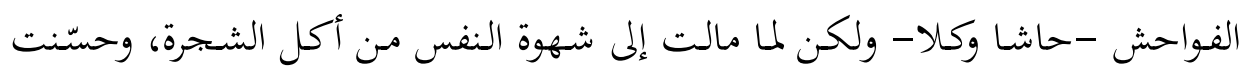

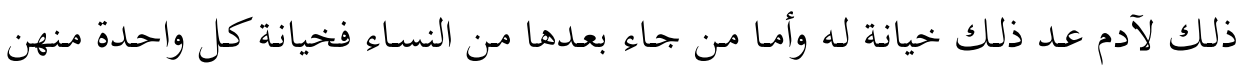

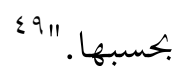

ولا أدري حقيقة لم أُلصق هذا الحمديث بحادثة خروج آدم وحواء من الجنة كما يراها

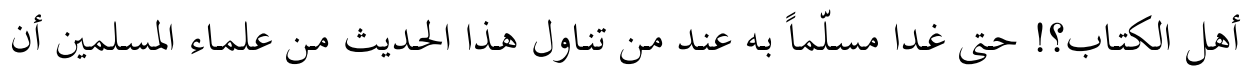

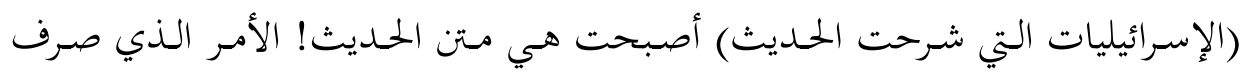

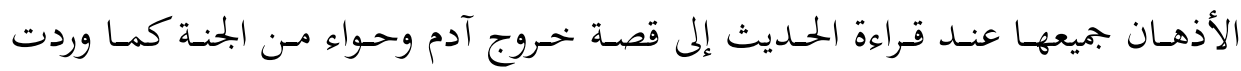
عندهم، وأن حواء هي الأصل في هذا الخروج كما تقول الإسرائيليات.

$$
\text { والسؤال المهم هنا: هل للحديث علاقة بالإسرائيليات؟! }
$$

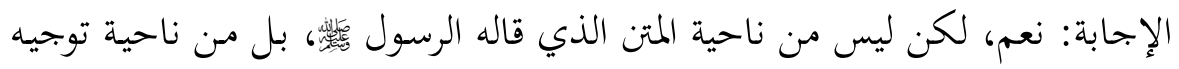
الشراح والمفسرين له، فقد كان التوجيه بناء على ما ورد من إسرائيليات تتعلق بخروج آدم

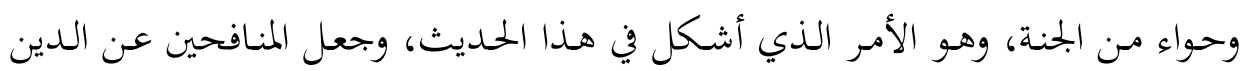

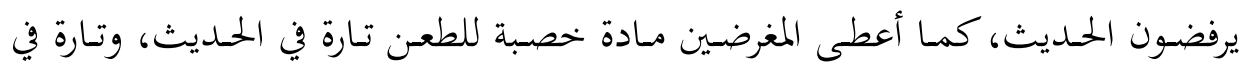
الصحابي، وتارة في الرسول الكريم إئل وأسأل هنـا سؤالاً: لماذا ارتضى علمـاء المسلمين التفسير المستقى مـن الإسرائيليات للحـديث، وهو مخالف لما جـاء بـه القـرآن، وابتعـدوا عن شرح الحـديث بنـاء على النظرة الإسلامية المتوافقة للقرآن؟! وهل يعقل أن نقبل أن يشرح الحديث الروايات الإسرائيلية، بـاء 
ونبتعد عن منهجية الإسلام في النظر إلى دور آدم وحواء (أو قل الرجل والمرأة) في إعمار الكون؟!

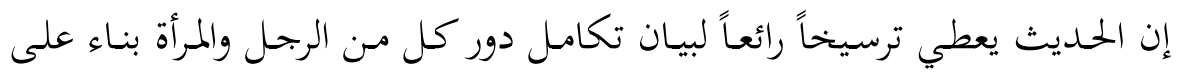

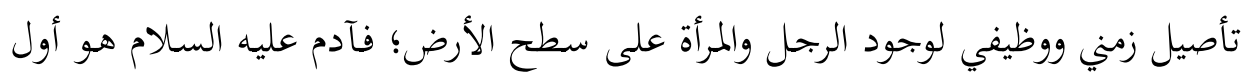

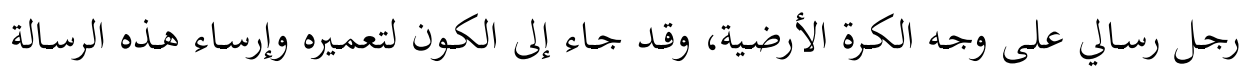

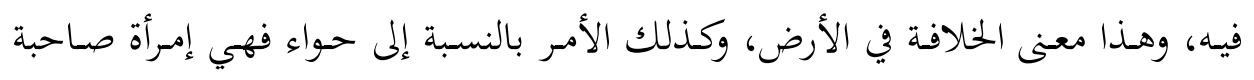

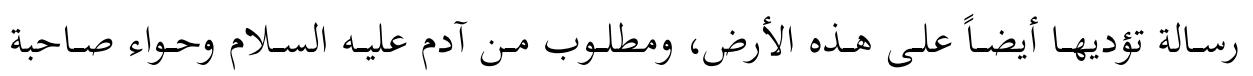

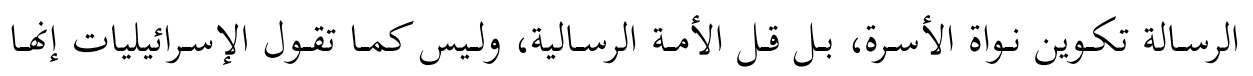

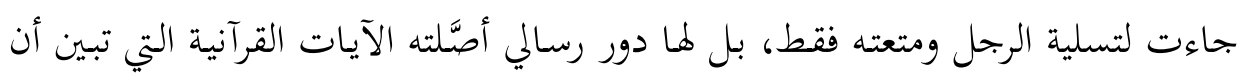

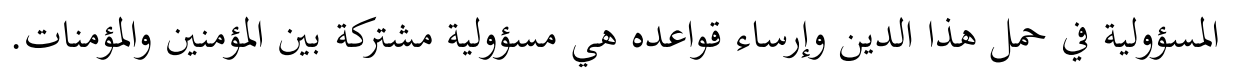

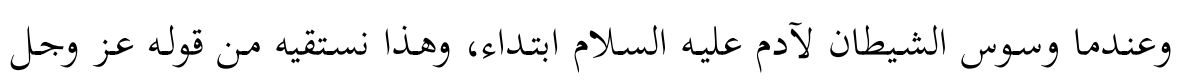

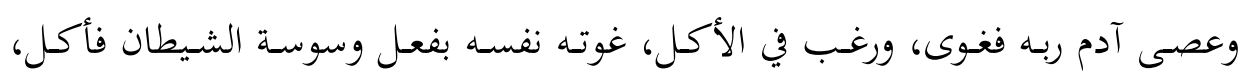

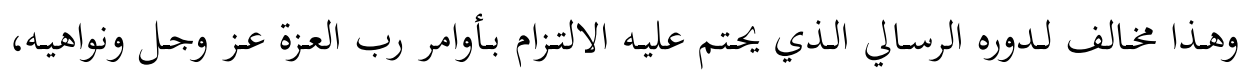

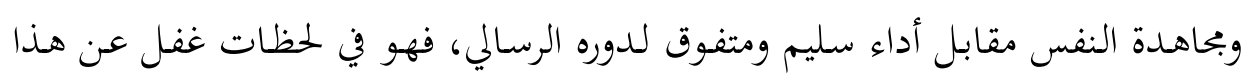
الدور، واتبع هواه، لكن سرعان ما رجع وتاب، فتابل أنساب الله عليه.

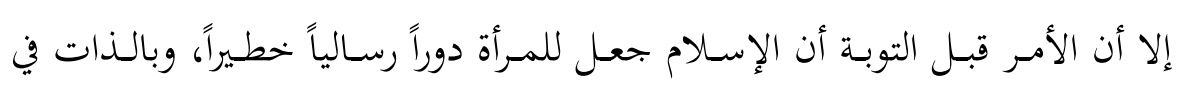

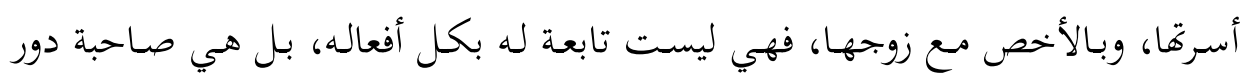

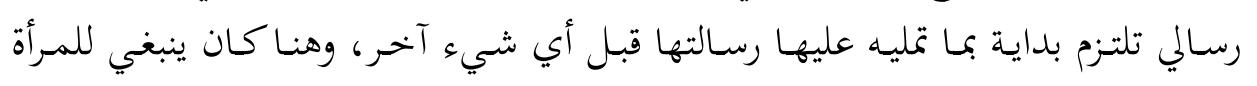

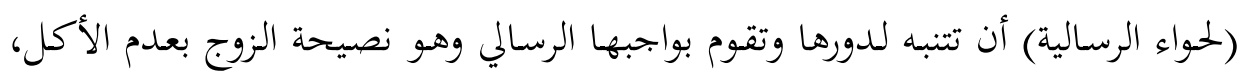

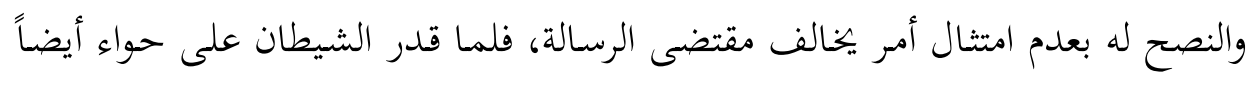

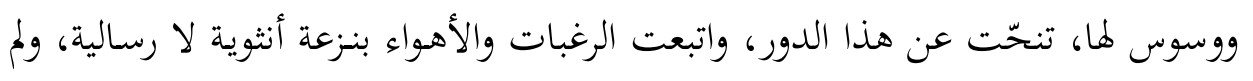

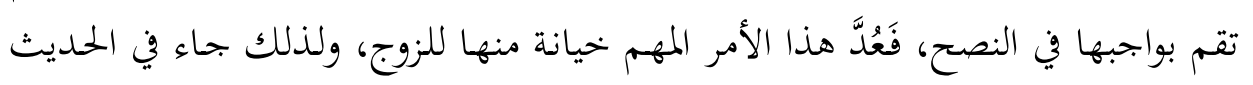
(لم تخن أنثى زوجها)، ولم يقل (لم تخن امرأة زوجها)

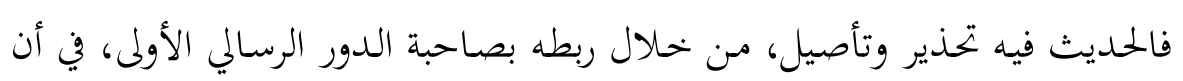

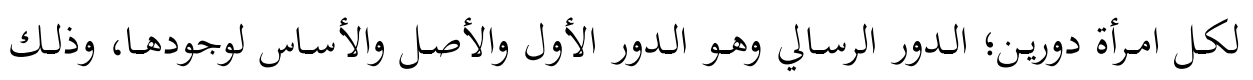


بمشاركتها الرجل الرسالي في حمل الأمانة وإعمار الكون. والدور الثاني وهو الدور الأنثوي

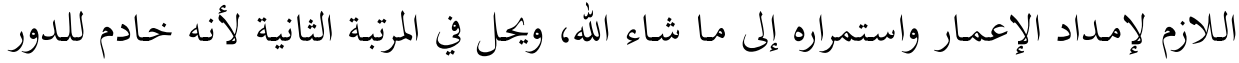
الأول، وفيه النزوات والشهوات التي قد يضبطها الإسلام ويحددها ليكون أداؤها في دورها

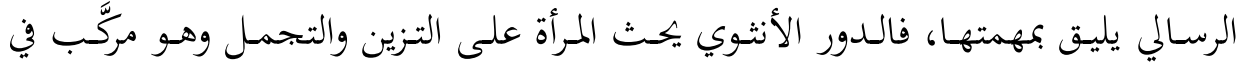
أنوثتها، إلا أنه إذا تعارض مع دورها الرسالي في أحد مناحي الحياة، تقدَّم دورها الرسالي.

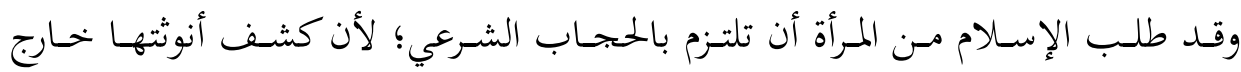

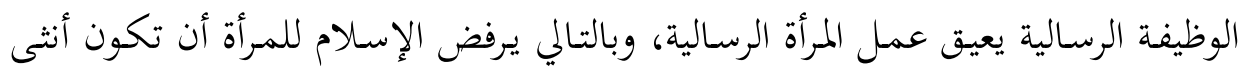

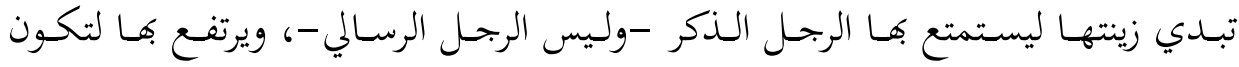

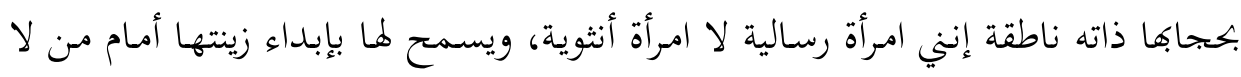
يعيقون بنظرهم إليها دورها الرسالي.

ولهذا الفهم تأصيل لغوي؛ إذ تستخدم الخيانة بأكثر من معنى، إلا أن المعنى الأصيل

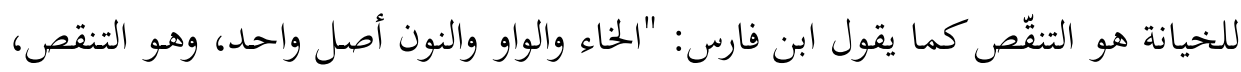

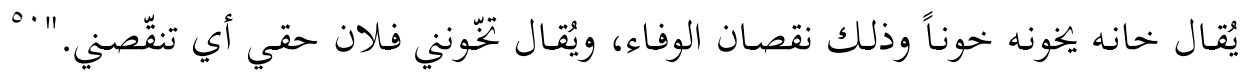

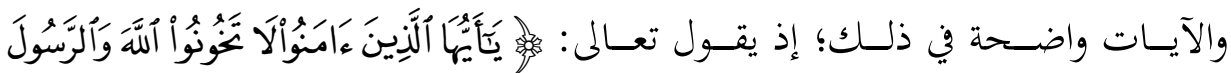

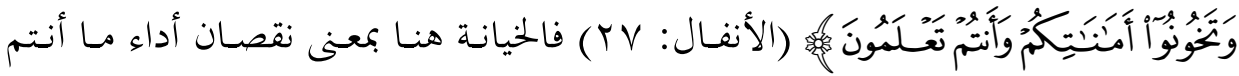

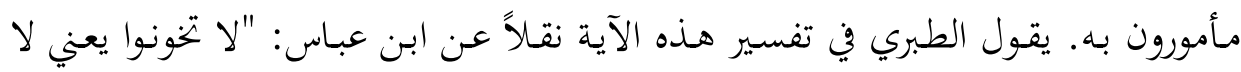

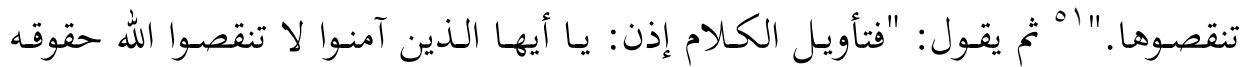
عليكم من فرائضه، ولا رسوله من واجب طاعته عليكم، ولكن أطيعوهما فيما أمراكم به لنه

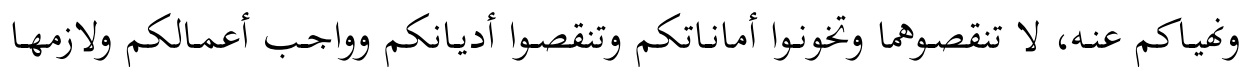

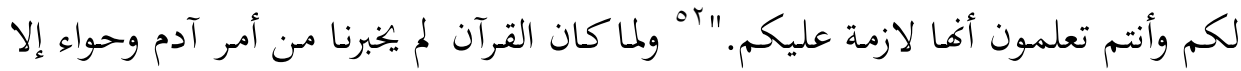

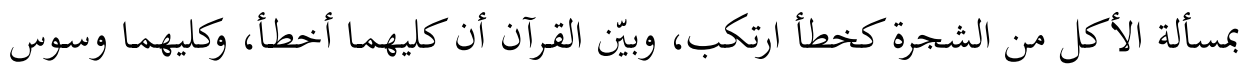

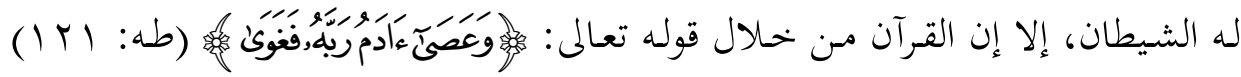
• ابن فارس، أحمد. معجم مقاييس اللغة، تحقيق وضبط: عبد السلام هارون، بيروت: دار الفكر للطباعة والنشر،

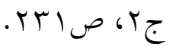

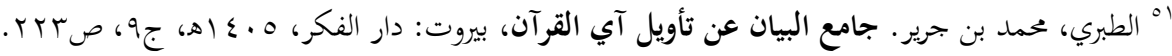

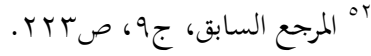




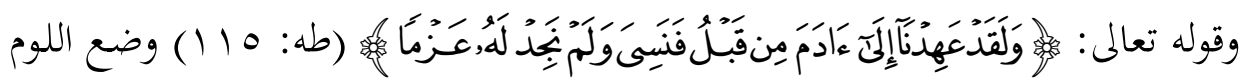

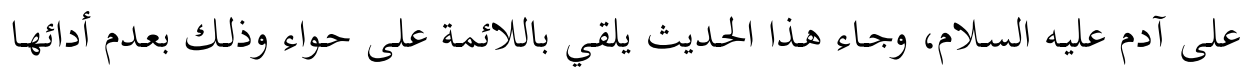

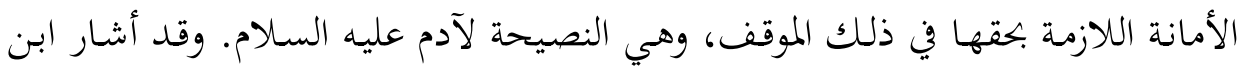

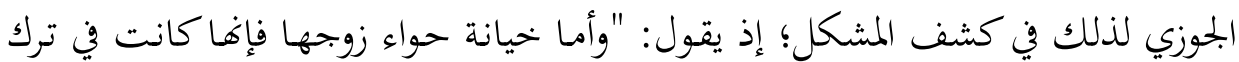

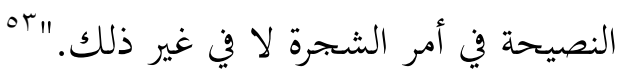

هكذا ينبغي أن يفهم الحـديث؛ أن فيه نوعاً مـن التقريع للمرأة التي عَمّش دورهـا

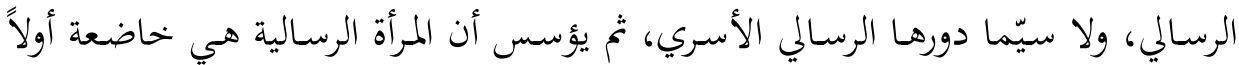

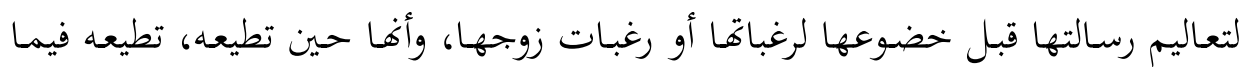

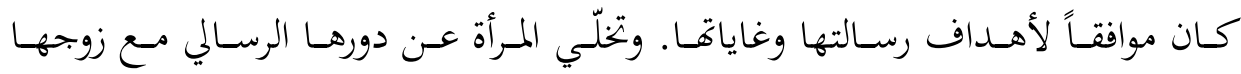

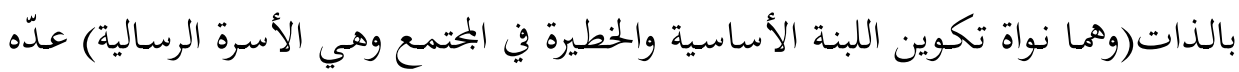

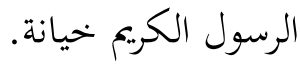

فالحمديث لا يُلقي باللوم والتبعة على حواء فقط إذا لم تقمم المرأة بدورها الرسالي،

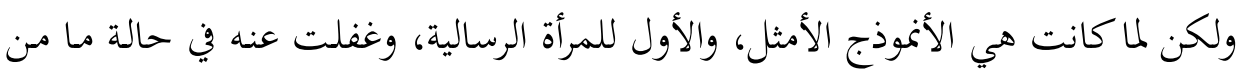

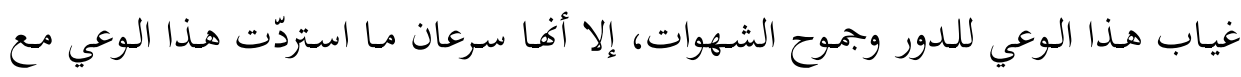

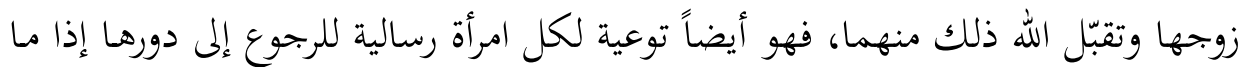

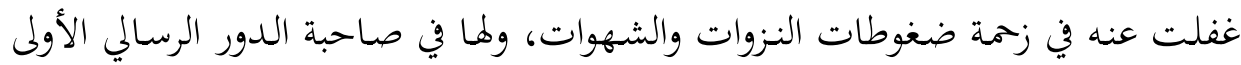
قدوة، والله تعالى أعلم.

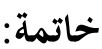

يعد هذا البحث خطوة أولى في سلسلة تبني منهجية علمية للتعامل مع السنة النبوية

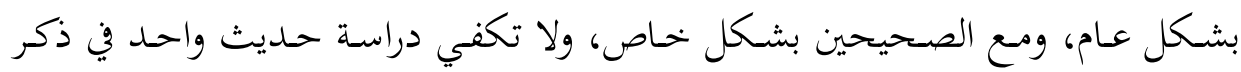

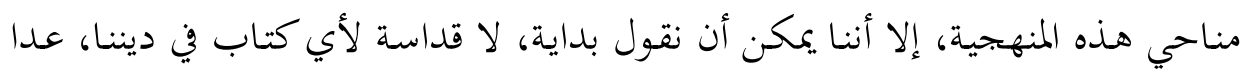
ro ابن الجوزي، أبو الفرج، كشف المشكل من حديث الصحيحين، تحقيق: علي حسين البواب، الرياض: دار

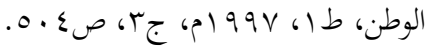




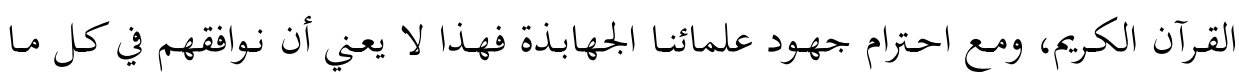

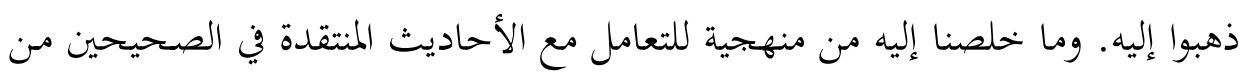

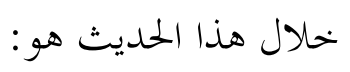
ا ـ على من يريد التوقف في حسديث في الصحيحين عليه أن يدرسه دراسة علمية

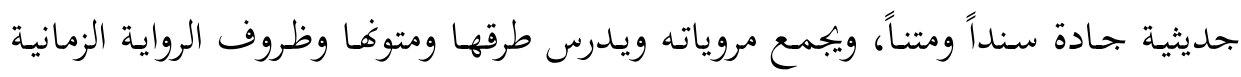
والمكانيـة والشخصية، ويقـف على أقوال العلمـاء فيـه، ومعـاني اللغـة لألفاظه وتركيباته.

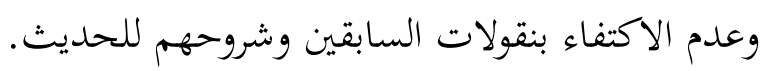

r . إن كان هنـاك أية محاولة جـادة بمنهجيـة علمية لحل الإشكال مـن خهلال فهـم معين، أو تأويل قريب تحتملهما اللغة ويحتمله الحديث، يُصار إليه دون تسفيه للموافق أو ادوليه المخالف. معنئ.

r. رفض التشنج لـدى أي من الفريقين، فردّ الحسيث لا يعني بالضرورة نوايا سيئة

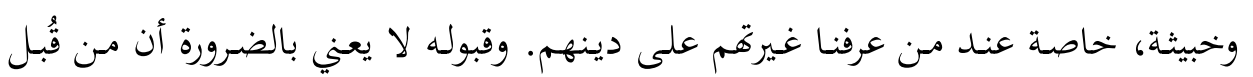
مخلص غيور على دينه بخلاف الآخر. ع. إذا استكمل الحديث شروط الصحة سنداً ومتناً واستشكل قبوله عقلياً -إلا أنه

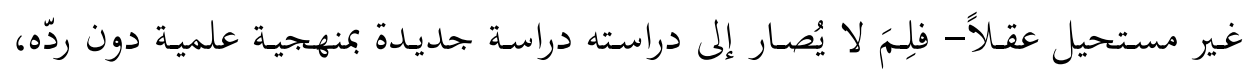
حتى نصل إلى نتيجة: إما قبوله أو (التوقف فيه) عسى الله أن يفتح على أحدهم. هـ هنــاك ثوابـت :لا رد لحــديث دون الرجــوع لأهـل التخصـص، ولا طعـن في الصحابي راوي الحديث المنتقد، ولا للإسرائيليات في شرح الحديث أو النص القرآين مهما استشكل فهمه، ولا عصمة لأقوال الصحابة والتابعين ومن بعدهم من السلف الصالح. جـ لا بدّ من فهم منهجية المصنف، الذي نطعن بإيراده رواية حديثية، فكثير ممن

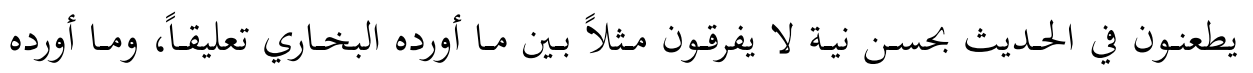

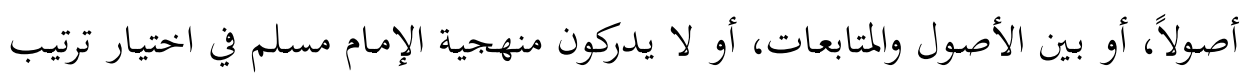
الحديث المعلل. 